\title{
The Environmental Competitiveness of Small Modular Reactors: A Life Cycle Study
}

\author{
Travis S. Carless ${ }^{\mathrm{a}, \mathrm{d}, 1}$ \\ W. Michael Griffin ${ }^{a}$ \\ Paul S. Fischbeck ${ }^{\text {a,b }}$
}

a. Carnegie Mellon University, Department of Engineering and Public Policy

Engineering, 129 Baker Hall, Pittsburgh, PA 15213, USA

b. Carnegie Mellon University, Department of Social and Decision Sciences, Pittsburgh, PA 15213, USA

c. Corresponding author. Tel.: +1 917-653-2031; fax: +1 412-268-3757.

E-mail addresses: tscarles@andrew.cmu.edu (T.S. Carless), wmichaelgriffin@cmu.edu (W.M. Griffin), pf12@andrew.cmu.edu (P.S. Fischbeck).

1. Permanent Address: Department of Engineering and Public Policy, Carnegie Mellon University, 129 Baker Hall, Pittsburgh, PA 15213.

Keywords:

Nuclear Power

Small Modular Reactors

Life Cycle analysis

Greenhouse gas

Uncertainty 


\begin{abstract}
This work conducts a prospective attribution life cycle assessment of an SMR. Monte Carlo simulation and sensitivity analyses are used to account for the uncertainties in the analysis. The analysis finds that the mean (and 90\% confidence interval) life cycle GHG emissions of the Westinghouse SMR (W-SMR) to be $9.1 \mathrm{~g}$ of $\mathrm{CO}_{2}$-eq/kwh (5.9 to $13.2 \mathrm{~g}$ of $\mathrm{CO}_{2}$-eq/kwh) and the Westinghouse AP1000 to be $8.4 \mathrm{~g}$ of $\mathrm{CO}_{2}$-eq/kwh (5.5 to $12.1 \mathrm{~g}$ of $\left.\mathrm{CO}_{2}-\mathrm{eq} / \mathrm{kwh}\right)$. The GHG emissions of the AP1000 are $9 \%$ less than the WSMR. However, when the nuclear fuel cycle is not included in the analysis the GHG emissions for the W-SMR and the AP1000 are effectively the same given the inherent uncertainties in the analysis. However, the analysis finds that both types of plants stochastically dominate the Generation II 4 loop SNUPPS. The mean (and 90\% confidence interval) life cycle GHG emissions of the SNUPPS is $13.6 \mathrm{~g}$ of $\mathrm{CO}_{2}$-eq/kwh (10.5 to $17.3 \mathrm{~g}$ of $\mathrm{CO}_{2}-\mathrm{eq} / \mathrm{kwh}$ ). While the AP1000 has the benefits of economies of scale, the W-SMR's modular ability enables it to make up some of the difference through efficiencies in construction, operation and maintenance, and decommissioning.
\end{abstract}




\section{Introduction}

In an effort to mitigate climate change, the United States (US) pledged to reduce their greenhouse gas (GHG) emissions over the next 10 years by 26\%-28\% below 2005 levels [1]. To meet this goal the US Environmental Protection Agency (EPA) finalized the Clean Power Plan regulation to reduce carbon pollution by establishing GHG emission guidelines for existing fossil-fuel power plants [2, 3]. In 2013, the EPA estimated that electricity generation accounted for $37 \%$ of all $\mathrm{CO}_{2}$ emissions in the United States [4]. In this calculation the EPA accounted for an additional $5.5 \mathrm{GW}_{\mathrm{e}}$ of nuclear capacity that is currently under construction in Georgia, South Carolina, and Tennessee [5]. With the early retirement of Vermont Yankee, Crystal River, San Onofre, Kewaunee, FitzPatrick, and Pilgrim nuclear power facilities, there will roughly be no net gain of installed nuclear capacity. It is estimated that if license renewals are not extended beyond a 60 -year lifetime, $30 \%$ of installed capacity will be lost by 2035 [6]. In the Clean Power Plan regulation, the EPA assumes that nuclear power plants will continue to run and does not account for any early retirements due to low natural gas prices and large maintenance costs.

The US Energy Information Administration (EIA) estimates that the demand for electricity in the United States will increase by 29\% between 2012 and 2040 [7]. While the EIA estimates that the natural gas (NG) share of total generation will increase [7], NG plants are not well suited to reduce GHG emissions as a bridge fuel. Though NG plants produce roughly half the GHG emissions as a coal-fired plant, fugitive emissions from upstream operations may negate the GHG emission reductions gained $[8,9]$. It is estimated that renewables will contribute $16 \%$ of total US electrical generation by 2040 [7]. However, though wind and solar produce no GHG emissions during operation, their intermittency and capacity factors, $35 \%$ and $25 \%$ [10], respectively are unable to provide reliable base-load energy. NG power plants often times serve as backup to intermittent renewable energy sources such as wind and solar. To meet the estimated $29 \%$ increase in electricity demand, an increase in nuclear power using small modular reactors (SMRs) may help meet future energy needs and provide affordable low-carbon electricity.

The capital cost associated with nuclear power is a major deterrent in the expansion of nuclear capacity. Federal loan guarantees authorized by the Energy Policy 
Act of 2005 can be allocated to projects that help reduce greenhouse gases by employing new technologies [11]. These loan guarantees can save utilities billions in financing charges. The lower capital cost of SMRs allows federal loan guarantees to be spread across more utilities or may provide options for firms to find financing options outside of the US federal government. The intermittency of renewables, their significant land use needed per MW, and their reliance on fossil fuels as backups or energy-storage technology that is still in its infancy make SMRs a viable option. To help accelerate development of SMRs, the US Department of Energy has appropriated \$452 million for the Small Modular Reactor Licensing Technical Support program over a six-year period. To date, funding has been provided to mPower American and NuScale Power in support of this goal.

There has been work in estimating the levelized cost of electricity (LCOE) of SMRs [12], to date there are no studies that estimate their life cycle GHG emissions. This study estimates the life cycle GHG emissions of SMRs. SMRs have the potential to be competitive with renewables and fossil fuels as the "middle option" if SMRs can be shown to be (i) more available and cost effective than renewables and (ii) generating less GHGs than fossil fuels. Estimates indicate that large advanced nuclear will have a lower LCOE than solar, offshore wind, and biomass [10]. When considering the GHG emissions produced over the lifetime of a nuclear power plant (NPP) using a life cycle assessment (LCA), nuclear power generally falls between renewables (e.g. wind and solar) and fossil fuels (e.g. natural gas and coal) [13]. In the past there have been several LCAs [13-15] on the GHG emissions from generation II 1,000 MWe NPPs. Warner and Heath (2012) performed a harmonization of LCAs for light water reactors to find that the median life cycle emissions could be 9 to $110 \mathrm{~g}$ of $\mathrm{CO}_{2}$-eq $/ \mathrm{kwh}$. The wide variation in estimates are attributed to the primary energy mix, the uranium ore grade used during mining, the LCA method, and assumptions made by each author such as including an alternate scenario where global decrease in the availability of current average uranium ore grades. These studies do not give a clear indication to where SMRs will fall in terms of cost and life cycle GHG emissions relative to other sources of electricity. 
While there are many commonalities between Generation II and III $+{ }^{1}$ nuclear plants and SMRs, there are key differences inherent in the design of SMRs such as:

- Longer refueling cycles

- Increased thermal efficiency

- Improved construction efficiency through modularity

- Shorter, more efficient supply chain

- Lower operation and maintenance costs

- Reduction in construction time and mass production

- Simpler decommissioning

The costs and benefits of these differences are explained in further detail in Appendix A.1.

The operating licenses of the current fleet of nuclear power plants are expected to begin expiring in 2029, while some power plants face early retirement. Some NPPs incur the added risk of early retirement because of the sheer age of these plants and inability to compete financially with NG plants. Additional investments in new capacity can explored to replace the capacity that maybe lost, meet future energy demand, and reduce GHG emissions.

This paper develops estimates of the life cycle GHG emissions of a Westinghouse iPWR SMR (W-SMR), an AP1000, and a 4-Loop Standardized Nuclear Unit Power Plant System (SNUPPS) across the nuclear fuel cycle, construction, operation and maintenance, and decommissioning stages of each plant. These estimates are used to show generational improvements in NPPs and to determine if the key features of an SMR result in a reduction in life cycle GHG emissions. These findings are used to estimate the cost of carbon abatement needed for SMRs to compete with fossil fuel power plants.

\section{Methods}

The guidelines and framework presented in ISO 14044 provide a basis for our life cycle assessment. Process chain analysis (PCA) was primarily used when inventory data was available for each stage such as mining and milling, conversion, fuel fabrication and enrichment. In the event that inventory data was not available, an environmentally

\footnotetext{
${ }^{1}$ Generation I reactors are non-commercial, early prototype or research reactors. Generation II reactors are current nuclear power plants in commercial operation built between 1965-1996. Generation III+ reactors are evolutionary improvements in standardization, fuel technology, thermal efficiency, and passive safety systems over Generation II plants. Generation IV reactors are designs generally not expected to achieve commercial maturity until 2030.
} 
extended economic input output method (EIOLCA) [16] was utilized. It is common practice to utilize the EIOLCA method for the operation and maintenance stage $[17,18]$. The construction stage utilized a combination of methods from PCA and EIOLCA. A PCA was used to calculate the production of materials, equipment use, and employee transportation. The EIOLCA method was used to calculate the emissions generated from the production of the Instrumentation and Control system (I\&C). Inventory data for the I\&C system of an NPP was not available; therefore, the cost of the system was used to determine emissions. The combination of PCA and EIO has been used in several LCA review papers (e.g., Sovacool (2008), Beerten et al. (2009), Warner and Heath (2012)). The input data for this study were sourced from literature on the nuclear fuel cycle, modular construction methods, and LCA on Generation II NPPs.

\subsection{Goal and Scope Definition}

The goal of this study is to estimate the cradle-to-grave US-centric life cycle GHG emissions of an $\mathrm{n}^{\text {th }}$ of a kind SMR for comparison to Generation II and III+ NPPs. This study encompasses mining, milling, conversion, enrichment, fuel fabrication, construction, operation, maintenance, and decommissioning of each NPP. Currently, the US does not recycle or reprocess spent nuclear fuel; as a result, a once-through nuclear fuel cycle is assumed. There are uncertainties in each stage of our LCA. To account for this, Monte Carlo simulations and sensitivity analysis were implemented. While the stages related to the nuclear fuel cycle are similar in each reactor, ${ }^{2}$ there are differences in the construction, operation, maintenance, and decommissioning stages. Many Generation II NPPs in the US were constructed in the 1970s and are non-standardized products. Generation III+ NPPs benefit greatly by the introduction of standardization and modularity. While proposed SMRs are designed to provide around $20 \%$ of the power of a $1,000 \mathrm{MW}$ unit plant and on the surface may seem to lose economic leverage on the basis of economies of scale [19], SMRs are based on the idea of modularity by allowing for $100 \%$ of the plant to be built in factories and assembled onsite. Because of this added modularity, SMRs can offset the loss in economies of scale and for some metrics may

\footnotetext{
${ }^{2}$ In this study the Generation II, Generation III+, and SMR are enriched to $3.60 \%, 4.55 \%$, and $4.95 \%$ respectively. Lower enrichment levels produces additional uranium needed for fuel fabrication, which produces additional emissions.
} 
perform better than 1,000 $\mathrm{MW}$ e units. This study aims to determine the environmental competitiveness of SMRs when including the value of modularity, size, standardization, and their ability to be fully fabricated in a factory and assembled on-site.

Within the US, there are two types of commercial NPPs, Pressurized Water Reactors (PWRs) and Boiling Water Reactors (BWRs). PWRs are the most common type of commercial reactor operating in the US, making up $66 \%$ of the total fleet and represent the 5.5 GW future installed capacity. Most generation III+ designs including the Advanced CANDU Reactor, the AP1000, the European Pressurized Reactor, the APR1400, and the VVER-1200/1300 are PWRs. Because PWRs are more common and are the technology of choice for most generation III+ reactors, the SNUPPS, AP1000, and W-SMR PWRs were analyzed here.

The Westinghouse designed Sizewell B NPP (SNUPPS) sited in Suffolk, England, UK was selected as the representative Generation II reactor because of data availability. The Westinghouse AP1000 was selected as the base model for the Generation III + reactor because of data availability on construction (i.e., four reactors under construction in Georgia and South Carolina).

The SMR modeled is an integrated PWR (iPWR). An iPWR SMR is considered a Generation III+ plant based on its evolutionary design and technological maturity. However, Generation IV SMR designs do not use water as a neutron moderator and are not expected to achieve commercial maturity until 2030. By definition SMRs produce an electrical output of $300 \mathrm{MW}_{\mathrm{e}}$. The iPWR design was selected because it is generally accepted that it will be the SMR technology that will face the least amount of regulatory hurdles [20], as it is based on current technology, which reduces uncertainty in a conservative nuclear industry. The Westinghouse designed $225 \mathrm{MW}_{\mathrm{e}} \mathrm{SMR}$ (W-SMR) was selected as the base model for SMRs because its design is based on the AP1000, reducing the complexity in estimating construction methods and material needed during construction; however, this similarity to the AP1000 may reduce differences between the two designs.

\subsection{Functional Unit}

A functional unit of kwh of electricity generated by each NPP was used. The life cycle inventory results are reported in $\mathrm{g}$ of $\mathrm{CO}_{2}-\mathrm{eq} / \mathrm{kwh}$ for NPP comparison. 


\subsection{System Boundary}

The system boundary defines the stages and components as well as flows of energy, waste and materials within the NPP life cycle in this analysis (Figure 1). Each stage, process, and flow is common among all three power plants. The life cycle stages and sub-processes include:

- Nuclear Fuel Cycle

o Uranium mining and milling

o Conversion

o Enrichment

o Fuel fabrication

- Construction

o Construction material production

o Construction worker travel

o Equipment use

- Operation and Maintenance

o Power plant employee travel

o Repair, replacement, and refurbishment

- Decommissioning

o Facility and building deconstruction

o Radioactivity measurements

o Cutting and decontamination

o Interim storage 


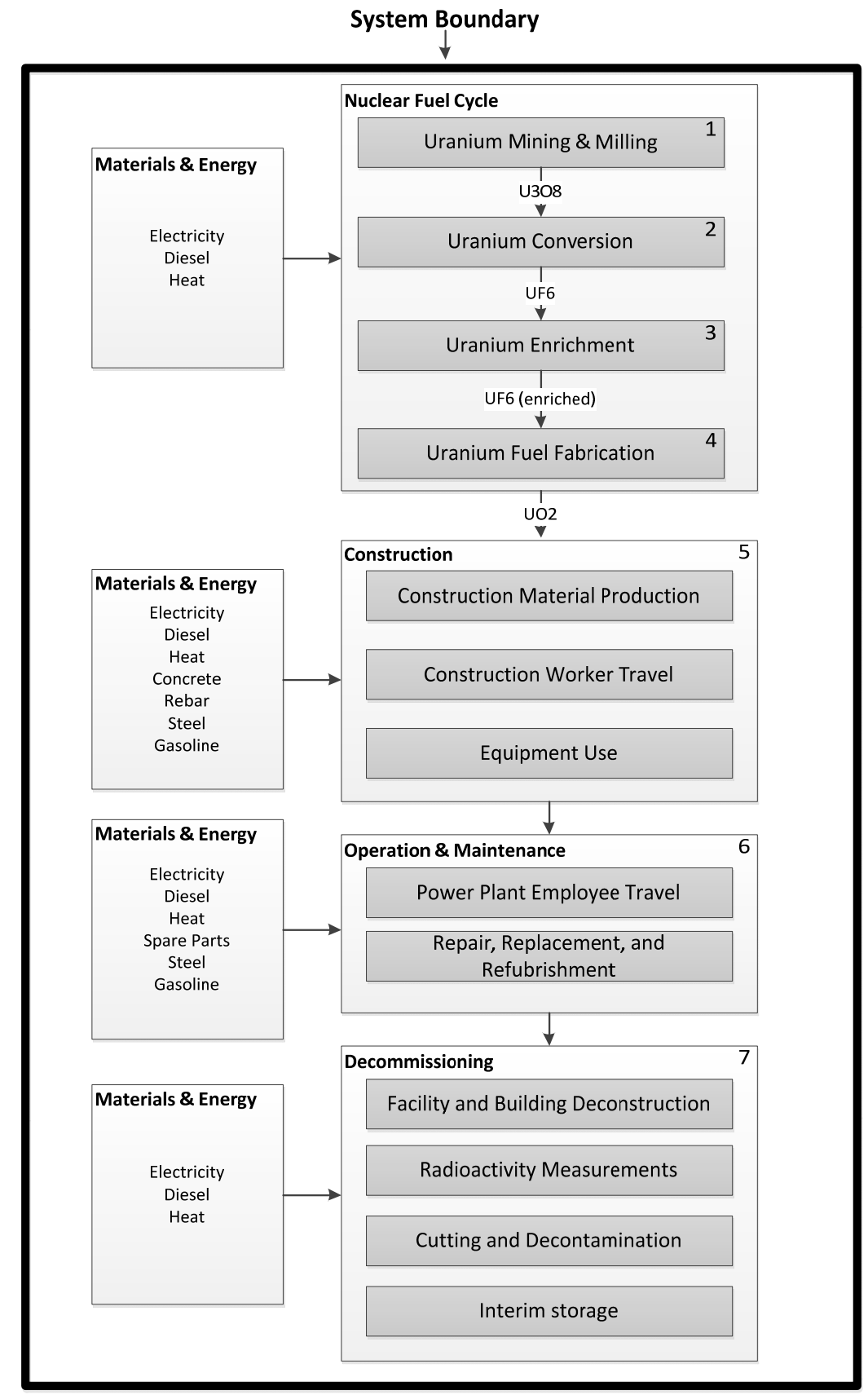

Figure 1. Life cycle Process and Material Flow of the Modeled Nuclear Power Plants. 


\subsection{Assumptions}

As with any LCA, assumptions of plant performance and input data are necessary. The assumptions for each power plant, the uranium fuel needed per year, and the associated nuclear fuel cycle are shown in Table 1. Gas centrifugation is assumed to be the only enrichment method used (see Appendix A.2). The W-SMR capacity factor, construction duration, and lifetime electricity produced are uncertain parameters. The capacity factor is estimated using the W-SMR refueling outage duration distribution. As such, the W-SMR uranium mass balance parameters vary based on the W-SMR refueling outage distribution duration outlined in Table 3.

\section{Table 1.}

Nuclear Power Plant Specification Parameters.

\begin{tabular}{lrrr}
\hline Description & SNUPPS & AP1000 & W-SMR \\
\hline Current Status & Existing & Under Construction & Proposed \\
Reactor Type & PWR & PWR & iPWR \\
Electrical Output $\left(\mathrm{MW}_{\mathrm{e}}\right)$ & 1,200 & 1,117 & 225 \\
Thermal Output $\left(\mathrm{MW}_{\mathrm{t}}\right)$ & 3,500 & 3,415 & 800 \\
Thermal Efficiency & $34 \%$ & $33 \%$ & $28 \%$ \\
Core Power Density $\left(\mathrm{MW}_{\mathrm{t}} / \mathrm{t} \mathrm{U}\right)^{3}$ & 39.3 & 40.4 & 30.4 \\
Total Core Load (tonnes U) & 89.1 & 84.5 & 26.3 \\
Fuel Assemblies & 193 & 157 & 89 \\
Feed Assemblies & 80 & 64 & 36 \\
Lifetime (years) & 60 & 60 & 60 \\
Capacity Factor & $90 \%$ & $90 \%$ & $97 \%$ \\
Refueling Cycle (months) & 18 & 18 & 24 \\
Construction Duration (months) & 96 & 60 & 24 \\
Lifetime Electricity Produced (TWh) & 568 & 520 & 114 \\
Concrete (million tonnes) & 1.24 & 0.24 & 0.08 \\
Rebar (thousand tonnes) & 65 & 12 & 4 \\
\hline Note: The capacity factor, construction duration, and the amount of concrete and rebar for the W-SMR are \\
the reported means from Monte Carlo simulation. The parameters for the distributions used are defined in \\
Table 3. & \multicolumn{3}{|}{}
\end{tabular}

\footnotetext{
${ }^{3}$ The core power density of the Westinghouse AP1000 and W-SMR is assumed to be 40.4 and $30.4 \mathrm{MWt} / \mathrm{t}$ U, respectively. [21] Brown JA. Comparison of 4-Loop, AP100, SMR Equilibrium Cycle Fuel Requirements. In: Carless T, editor. The Environmental Competitiveness of Small Modular Reactors: A Life Cycle Study Comments ed2016. p. 1.
} 
Table 2.

Uranium Mass Balance.

\begin{tabular}{lrrr}
\hline Description & SNUPPS & AP1000 & W-SMR \\
\hline Average Discharge Fuel Burnup (GWd/t U) & 49 & 51 & 51 \\
Required Uranium (tonnes/year) & 296 & 274 & 75 \\
Uranium Enrichment (Product Assay) & $4.6 \%$ & $4.5 \%$ & $4.9 \%$ \\
Tails Assay \% & $0.3 \%$ & $0.3 \%$ & $0.3 \%$ \\
Uranium Mill (tonnes $\left.\mathrm{U}_{3} \mathrm{O}_{8}\right)$ & 296 & 274 & 75 \\
Uranium Mill (tonnes U) & 251 & 233 & 63 \\
Conversion Uranium Loss & $0.5 \%$ & $0.5 \%$ & $0.5 \%$ \\
Conversion (tonnes UF 6 natural) & 369 & 342 & 93 \\
Conversion (tonnes U natural) & 250 & 231 & 63 \\
Enrichment Energy Consumption (GWhe) & 7.2 & 7.3 & 2.5 \\
Enrichment Separative Work Units ${ }^{5}$ (thousand SWUs) & 153 & 141 & 39 \\
Enrichment (tonnes UF6 enriched) & 35.1 & 33.2 & 8.3 \\
Enrichment (tonnes UF 6 depleted) & 334 & 309 & 84.9 \\
Enrichment (tonnes U) & 23.8 & 22.4 & 5.6 \\
Fuel Fabrication Uranium Loss & $1 \%$ & $1 \%$ & $1 \%$ \\
Fuel Fabrication (tonnes UO S $_{2}$ ) & 26.7 & 25.2 & 6.3 \\
Fuel Fabrication (tonnes U) & 23.5 & 22.2 & 5.6 \\
\hline
\end{tabular}

Note: The gas centrifuge enrichment energy consumption is based on mean of $63 \mathrm{kwh} / \mathrm{SWU}$ derived from a triangular distribution $(40,50,100 \mathrm{kwh} / \mathrm{SWU})$. The uranium mass balance of the W-SMR is based on a capacity factor of $97 \%$.

\subsubsection{W-SMR Capacity Factor and Construction Duration}

Recently, capacity factors for NPPs in the U.S. have improved to 90\% [23], from an average of $55 \%$ in the $1980 \mathrm{~s}$. This is due to a reduction in the amount of days required for a refueling outage. Today, typical regular maintenance runs concurrently with refueling for NPPs. Based on data from 2000-2013 (see Table A-1), the average refueling outage duration for a 1,000 MWe NPP is 40 days. A linear extrapolation of refueling outage duration of the $1,000 \mathrm{MW}_{\mathrm{e}}$ plant based on the electrical output of a $225 \mathrm{MW} \mathrm{W}-$ SMR is 9 days. The historical and linear extrapolated estimates for each year can be seen in Appendix A.2.1.

\footnotetext{
4 [21] Brown JA. Comparison of 4-Loop, AP100, SMR Equilibrium Cycle Fuel Requirements. In: Carless T, editor. The Environmental Competitiveness of Small Modular Reactors: A Life Cycle Study Comments ed2016. p. 1.

${ }^{5}$ Separative work units (SWUs) are "The standard measure of enrichment services. The effort expended in separating a mass $\mathrm{F}$ of feed of assay $\mathrm{x}_{\mathrm{f}}$ into a mass $\mathrm{P}$ of product assay $\mathrm{x}_{\mathrm{p}}$ and waste of mass $\mathrm{W}$ and assay $\mathrm{X}_{\mathrm{W}}$ is expressed in terms of the number of separative work units needed, given by the expression SWU $=$ $\mathrm{W} \times \mathrm{V}\left(\mathrm{x}_{\mathrm{w}}\right)+\mathrm{P} \times \mathrm{V}\left(\mathrm{x}_{\mathrm{p}}\right)-\mathrm{F} \times \mathrm{V}\left(\mathrm{x}_{\mathrm{f}}\right)$, where $\mathrm{V}(\mathrm{x})$ is the "value function," defined as $\mathrm{V}(\mathrm{x})=(1-2 \mathrm{x}) \times \ln ((1-$ $\mathrm{x}) / \mathrm{x})$." [22] Nuclear Engineering International, 2012. Digital switch.< http://www.neimagazine.com/features/featuredigital-switch/ > (May 7, 2015)
} 
Normal distribution statistics from Table A-1 are used to model refueling uncertainty for the W-SMR. As an upper bound, it is assumed that the refueling of a WSMR will not take longer than a traditional $1,000 \mathrm{MW}_{\mathrm{e}} \mathrm{NPP}$. As a lower bound, it is assumed, at minimum, on average, 9 days will be needed to refuel a W-SMR regardless of the plant size. In comparison, it is estimated that at minimum, 7 to 10 days are needed to refuel a large NPP [24]. This is because it is estimated that SMRs use about $20 \%$ of the fuel of a large NPP. The refueling duration can also be reduced based on a reduction in maintenance requirements for factory-fabricated modules. To account for the W-SMR refueling outage duration uncertainty, a uniform distribution was implemented using the normal distribution of linearly extrapolated values of the W-SMR as the minimum and the normal distribution of the historical values of the $1,000 \mathrm{MW}_{\mathrm{e}}$ plant as the maximum. Table 3 outlines the parameters for the W-SMR refueling outage duration uniform distribution. 


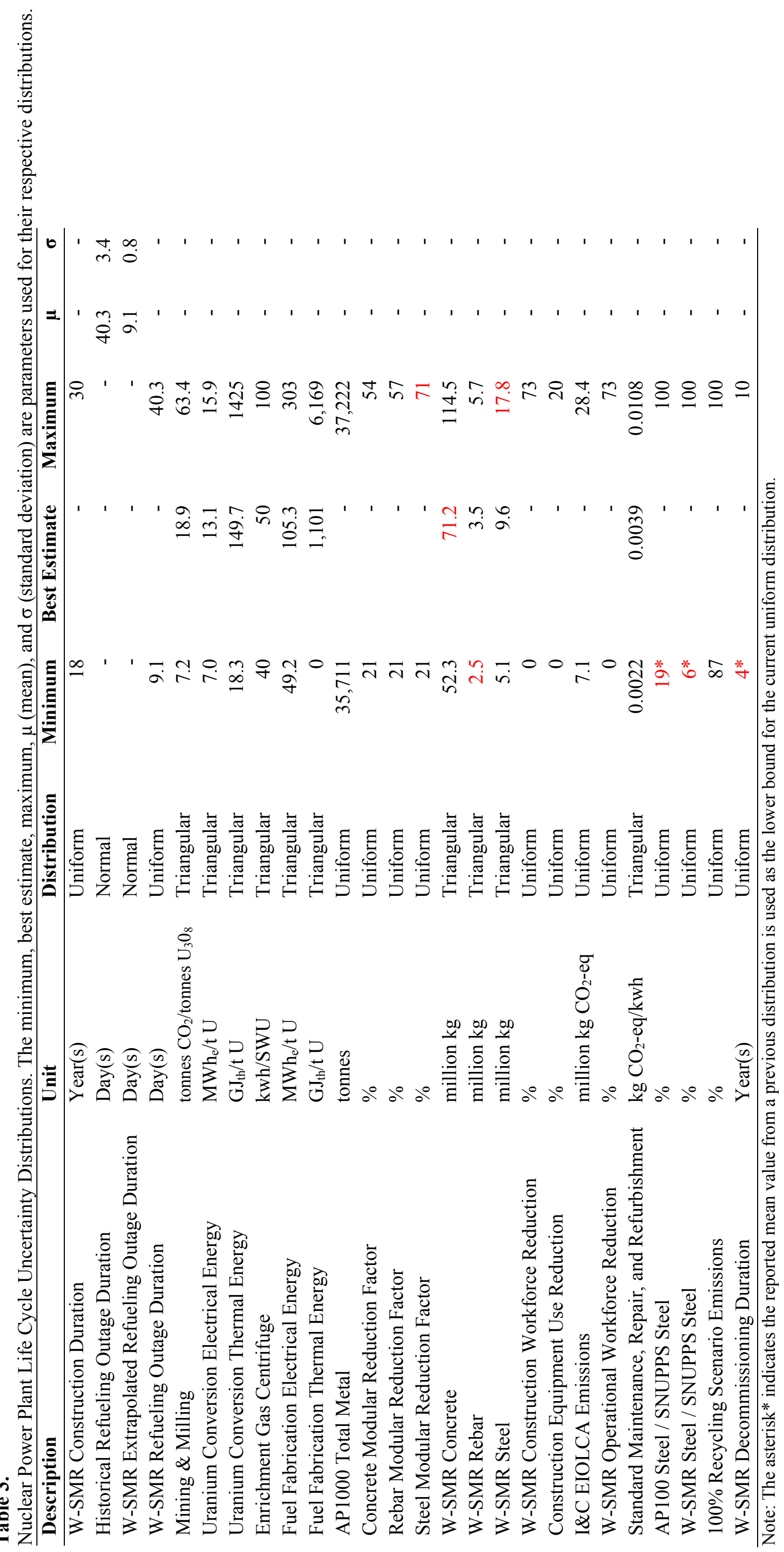




\subsection{Uranium Mining and Milling}

The uranium mining and milling stage is where uranium ore is extracted from the earth and processed into triuranium octoxide $\left(\mathrm{U}_{3} \mathrm{O}_{8}\right)$ or "yellowcake." (see Appendix A.3.) Three primary methods of mining are considered: in situ leaching, underground, and open pit mining. The World Nuclear Association estimates that 46\%, 37\%, and 17\% of uranium mining is done by in situ leaching, underground, and open pit, respectively $[25]$.

The ore grade of a uranium deposit has a large impact on energy use in the mining and milling stage of the uranium fuel cycle. The grade indicates the concentration of uranium within the ore. Lower ore grades require more material ore to be mined and processed to get the desired amount of uranium resulting in higher GHG emissions (see Appendix A.3). Table 4 outlines the mines, ore grades and emissions per tonne of $\mathrm{U}_{3} \mathrm{O}_{8}$ recovered from the mining and milling process $[6,26,27]$.

Table 4.

Mining \& Milling Ore Grades and Emissions [6, 26, 27].

\begin{tabular}{|c|c|c|c|c|c|}
\hline Uranium Mine & Mining Method & $\begin{array}{r}\text { Ore Grade } \\
\left(\% \mathrm{U}_{3} \mathrm{O}_{8}\right)\end{array}$ & $\begin{array}{r}\% \text { of World } \\
\text { Uranium } \\
\text { Production }\end{array}$ & $\begin{array}{r}\text { Emissions } \\
\left(\mathrm{t} \mathrm{CO}_{2} / t \mathrm{U}_{3} \mathrm{O}_{8}\right)\end{array}$ & $\begin{array}{r}\text { Standard Deviation } \\
\left(+/-\mathrm{t} \mathrm{CO}_{2} / \mathbf{t ~ U}_{3} \mathbf{O}_{8}\right)\end{array}$ \\
\hline Ranger & Open Pit & $0.28-0.42$ & $4 \%$ & 14.1 & 2.3 \\
\hline Olympic Dam & Underground & $0.064-0.114$ & $6 \%$ & 50.4 & 13.0 \\
\hline Rossing & $\begin{array}{l}\text { Open Pit } \\
\text { In-Situ }\end{array}$ & $\sim 0.034-0.041$ & $3 \%$ & 45.7 & 4.2 \\
\hline $\begin{array}{l}\text { Beverley } \\
\text { McArthur }\end{array}$ & Leaching & $\sim 0.18$ & $1 \%$ & 10.3 & 3.0 \\
\hline River & Underground & $\sim 14.24$ & $14 \%$ & 9.6 & N/A \\
\hline
\end{tabular}

The Ranger, Olympic Dam, Rossing, Beverley, and McArthur River uranium mines represent $28 \%$ of the world's total uranium production. The lack of data for other mining operations resulted in the use of these mines as a representative sample of total uranium production. Table 3 provides the mining and milling triangular distribution using the lowest available estimate from the Beverly mine $\left(+/-3 \mathrm{t} \mathrm{CO}_{2} / \mathrm{t} \mathrm{U}_{3} \mathrm{O}_{8}\right.$ standard deviation) and the Olympic Dam (+/- $13 \mathrm{t} \mathrm{CO}_{2} / \mathrm{t} \mathrm{U}_{3} \mathrm{O}_{8}$ standard deviation) mine for the highest available estimate. A weighted average of the GHG emissions from mining calculated by emissions from each mine, the world uranium production, and the mining method distributions (see Equation A-1) was used as the best estimate. 


\subsection{Conversion}

The uranium conversion stage is where the $\mathrm{U}_{3} \mathrm{O}_{8}$ is stripped of all remaining impurities and converted to hexafluoride (UF6). This three-step phase is detailed in Appendix A.4. Table 3 provides the parameters used in the electrical and thermal energy requirement triangular distributions to account for uncertainty among the estimates in Table A-2. An emission factor of $560 \mathrm{~g} \mathrm{CO}_{2}$-eq/kwh was assumed for the U.S. electrical grid [28]. This is used to convert the electrical energy needed during the conversion process to $\mathrm{kg} \mathrm{CO}_{2}$-eq. A high-efficiency boiler running at $80 \%$ efficiency is assumed for the thermal energy requirements to calculate the amount of $\mathrm{CO}_{2}$-eq/tonnes $\mathrm{U}$.

\subsection{Enrichment}

The enrichment stage is where the uranium in $\mathrm{UF}_{6}$ from the conversion stage becomes enriched to 3 to $5 \%$. There are two methods of enriching uranium, gaseous diffusion and gas centrifuge with the former being 40 times more energy intensive than the latter. Warner (2012) outlines previous studies where a combination of diffusion and centrifuge methods were used to enrich the uranium. Energy requirements for each enrichment method can be found in Appendix A.5. This study only includes the centrifuge method, because sole diffusion plant in Paducah, KY closed in May 2013.

Table 3 provides the parameters in a gas centrifuge triangular distribution to account for the energy requirement uncertainty. Table 2 outlines annual enriched uranium needed by each NPP. This is calculated from the UF6 obtained from the conversion stage and an assumed product (enrichment \%) and tails assay. Typically, the higher the product assay, the less enriched UF6 is produced during the nuclear fuel cycle. The amount of enriched UF6 is used to calculate the Separative Work Units (SWUs) needed in the enrichment process. The total lifetime emissions are calculated by multiplying the lifetime SWUs by the energy requirements of the centrifuge method.

\subsection{Fuel Fabrication}

The final stage in the nuclear fuel cycle is fuel fabrication where the enriched UF6 is converted to uranium dioxide $\left(\mathrm{UO}_{2}\right)$ in a powder form. The $\mathrm{UO}_{2}$ powder is then processed into pellets. Table 3 provides the parameters used in the electrical and thermal 
energy fuel fabrication triangular distributions ${ }^{6}$ among the estimates in Table A-3. Like the conversion process, the U.S. electrical grid emissions and $80 \%$ efficiency is assumed for the thermal energy requirements to calculate the amount of $\mathrm{CO}_{2}-\mathrm{eq} / \mathrm{t} \mathrm{U}$.

\subsection{Construction ${ }^{7}$}

The construction of each successive generation of 1,000 MWe NPP has become increasingly more efficient, using less concrete and less steel without sacrificing safety. Generation III+ plants such as the AP1000, employ modular construction methods that can lead to additional reduced construction time, materials, and waste generation. The AP1000 is estimated to use about $20 \%$ of the amount of concrete and rebar as a SNUPPS given the about the same electrical output. The AP1000 is able to use " $60 \%$ fewer valves, $75 \%$ less piping, $80 \%$ less control cable, $35 \%$ fewer pumps, and 50\% less seismic building volume than in a conventional reactor," [30] because it utilizes advanced modular construction methods with about 350 modular components. This reduces the total amount of construction material required to build the AP1000. While the W-SMR is considered $100 \%$ modular, there are no SMRs under construction or in commercial operation. As such, there is no data on the amount of concrete and steel required to build an SMR so these values were estimated by calculating the volume of concrete and steel in AP1000 containment building and scaling to the size of a W-SMR for the upper bound. Peterson et al. (2005) estimated the physical dimensions and the amount of steel and concrete needed to construct a General Atomics 286 MWe Gas Turbine Modular Helium Reactor (GT-MHR) SMR. A lower bound was calculated by scaling the containment volume to the size of a W-SMR (see Appendix A.7).

There are no data available on the benefits of modularity to a NPP. A case study [31] estimates the emissions from the construction of modular homes and traditional homes built on-site (see Appendix A.7.1). The modularity reduction from the SNUPPS in concrete, rebar, and steel was used to set the minimum of the modular reduction factor

\footnotetext{
${ }^{6}$ The reported mean is used as the best estimate for the triangular distribution.

${ }^{7}$ Emission factors of $0.4 \mathrm{~kg} \mathrm{CO}_{2}$-eq $/ \mathrm{kg}$ of concrete, $4.4 \mathrm{~kg} \mathrm{CO}$-eq $/ \mathrm{kg}$ of rebar, and $3.3 \mathrm{~kg} \mathrm{CO}_{2}$-eq $/ \mathrm{kg}$ of steel were assumed [29] Voorspools KR, Brouwers EA, D D'haeseleer W. Energy content and indirect greenhouse gas emissions embedded in 'emission-free'power plants: results for the low countries. Applied Energy. 2000;67(3):307-30.. Steel is assumed to be non-structural steel. Rebar is assumed to be structural steel.
} 
uniform distribution in Table 3. The maximum was set based on the percent change from the scaled W-SMR estimate from the AP1000 to the scaled up estimate from the GTMHR (see Appendix A.7.1).

These modularity reductions were factored into the scaled W-SMR estimates from the AP1000 for a best estimate. Table 5 outlines the utilization of a triangular distribution to account for uncertainty among the amount of concrete, rebar, and steel needed for a W-SMR.

\section{Table 5.}

W-SMR Material Distribution.

\begin{tabular}{lrrr}
\hline Description & $\begin{array}{r}\text { Scaled From } \\
\text { GT-MHR } \\
\text { (Min) }\end{array}$ & $\begin{array}{r}\text { Modular } \\
\text { Reduction } \\
\text { (Best Estimate) }\end{array}$ & $\begin{array}{r}\text { Scaled From } \\
\text { AP1000 } \\
\text { (Max) }\end{array}$ \\
\hline $\begin{array}{l}\text { Concrete Triangular } \\
\begin{array}{l}\text { Distribution (Million kg) } \\
\text { Rebar Triangular Distribution } \\
\text { (Million kg) }\end{array}\end{array}$ & 52.3 & 71.2 & 114.5 \\
$\begin{array}{l}\text { Steel Triangular Distribution } \\
\text { (Million kg) }\end{array}$ & 2.5 & 3.5 & 5.7 \\
\hline
\end{tabular}

Note: The modular reduction column contains the reported mean values from Monte Carlo simulation. The parameters are uncertain variables based on random draws from uniform distributions defined in Table 3 .

Chapman et al. (2012) provide estimates for the emissions from the construction workforce and equipment usage for a 1,000 $\mathrm{MW}_{\mathrm{e}}$ reactor. Table A-8 outlines the carbon emissions generated from transportation of the workers over the period of construction for each type of power plant. Additional details can be found in Appendix A.7.2. Table 3 outlines the W-SMR construction workforce emissions reduction from a typical 1,000 $\mathrm{MW}_{\mathrm{e}} \mathrm{NPP}$ using a uniform distribution. The minimum is $0 \%$ assuming there is no additional reduction from the estimate in Table A- 8 . The maximum is $73 \%$ based on the worker reduction in Table A-6.

The estimated annual carbon emissions generated from equipment usage during construction for a traditional 1,000 MW NPP [32] and a scaled estimate of a W-SMR are 3.34 and 0.64 million $\mathrm{kg} \mathrm{CO}_{2}$-eq respectively (see Appendix A.7.2). Table 3 outlines the W-SMR construction equipment emissions reduction uniform distribution. The minimum is $0 \%$ assuming there is no additional reduction from the scaled estimate from equipment usage. The maximum is $20 \%$ based on the worker reduction in Table A- 6 . 
The GHG emissions generated from the production of I\&C equipment for each NPP was estimated using EIOLCA [16]. Assuming low-end and high-end cost estimates of $\$ 25$ million and $\$ 100$ milion [22] and all equipment falls in sector $334111^{8}$ for electronic computer manufacturing, the estimated GHG emissions from I\&C production for a SNUPPS is between 7.1 and 28.4 million $\mathrm{kg}$ of $\mathrm{CO}_{2}$-eq. Table 3 outlines the uniform distribution used to estimate the emissions from SNUPPS I\&C production. The AP1000 and W-SMR GHG emissions are estimated by multiplying the percentage of component steel in an AP1000 and W-SMR compared to a SNUPPS (See Section 2.10).

\subsection{Operation and Maintenance}

The operation and maintenance (O\&M) is the stage where the GHG emissions from tasks such as operating diesel generators during an outage, employee travel to work, and repair, replacement, refurbishment, or upgrades that take place during each plant's lifetime are captured. A PCA analysis was used to estimate employee travel based on the methodology in Chapman et al. (2012), whereas an EIOLCA was implemented for the other tasks [17, 33]. Chapman et al. (2012) provides estimates for the emissions from employees traveling to work during the operation of a 1,000 MWe NPP. Table A-10 outlines the carbon emissions generated from transportation from the employees over the lifetime for each power plant. The commuting trips for the W-SMR were scaled based on the electrical output. To account for staffing uncertainty, a uniform distribution is used with the same parameters as the workforce reduction uniform distribution in Table $3 .{ }^{9}$

A triangular distribution is used to estimate the GHG emissions from maintenance, repair, and refurbishment for the SNUPPS. White and Kulcinski's (2000) estimate of $0.0022 \mathrm{~kg} \mathrm{CO}$-eq/kwh is used as the minimum, Fthenakis and Kim's (2007) estimates of the average and maximum, 0.0039 and $0.0108 \mathrm{~kg} \mathrm{CO}_{2}$-eq/kwh, are used as the best estimate and maximum respectively. Table 3 outlines the parameters for the standard maintenance, repair, and refurbishment triangular distribution.

\footnotetext{
${ }^{8}$ Sector 334111 of the North American Industry Classification System (NAICS) is used to classify economic activity of electronic computer manufacturing.

${ }^{9}$ Current regulations and staffing requirement ensure that one reactor operator and one senior reactor operator are required for the operation of one nuclear unit [34] United States Nuclear Regulatory Commission, 2014. § 50.54 Conditions of licenses. $<$ http://www.nrc.gov/reading-rm/doccollections/cfr/part050/part050-0054.html > (December 20, 2014), [34] ibid.. The inherent simplicity of a W-SMR could reduce the support staff significantly.
} 
The AP1000 uses about $20 \%$ of the non-structural steel as a SNUPPS. It is assumed components in NPPs, such as the reactor vessel, steam generator, and other equipment use non-structural steel in their production. Because these components generally require standard maintenance over time, the reduction in the amount of nonstructural steel needed was used to estimate a reduction in maintenance, repair, and refurbishment. Table 3 shows a uniform distribution where the minimum is the fraction of non-structural steel in an AP1000 and a W-SMR compared to a SNUPPS, respectively. The maximum value is $100 \%$, and assumes the AP1000 or W-SMR requires the same maintenance as a SNUPPS. The values from the standard maintenance, repair, and refurbishment triangular distribution were multiplied by the "AP100 Steel / SNUPPS Steel" and a "W-SMR / SNUPPS Steel" uniform distributions in Table 3 resulting in an estimate for $\mathrm{kg}$ of $\mathrm{CO}_{2}$-eq/kwh needed for maintenance, repair, and refurbishment of the AP1000 and W-SMR.

\subsection{Decommissioning}

The decommissioning stage involves dismantling, decontaminating, and removing the NPP. Additional details on decommissioning can be found in Appendix A.9. There is little data available on GHG emissions from NPPs in the U.S. Seier and Zimmerman (2014) is used as the basis for estimating GHG emissions from decommissioning of the Greifswald nuclear power station (KGR) in Germany because of the transparency and availability of data. For decommissioning stage, Seier and Zimmerman (2014) estimated KGR produced $11.27 \mathrm{~g} \mathrm{CO} 2-\mathrm{eq} / \mathrm{kWh}$. The reported GHG emissions are higher than other studies primarily because KGR operated for about 17 years with a capacity factor of about 77\%. While Seier and Zimmerman's (2014) analysis contained final storage, this was not included in our study because there is uncertainty with long-term storage solutions in the US. Typically, dry interim storage casks are housed in an outdoor storage area requiring a minimal amount of electricity compared to the electricity generated by the host NPP over its lifetime. 
The KGR 1,760 MWe NPP required 1.5 million tonnes of concrete during construction, and a SAFSTOR ${ }^{10}$ strategy was utilized for the decommissioning. The energy required to decommission a SNUPPS, AP1000, and a W-SMR are scaled relative to each reactor's concrete use compared to the KGR. The majority of parts and components of an NPP are not radioactive and as a result most parts can be recycled [35]. Seier and Zimmerman (2014) estimate for 100\% recycling of residual materials results in a 13\% reduction in GHG emissions. Table 3 outlines the recycling emissions uniform distribution. The minimum is a $100 \%$ recycling scenario where $87 \%$ of the emissions are produced from the $0 \%$ recycling scenario. The maximum is a $0 \%$ recycling scenario during decommissioning. Table 6 outlines the emissions for the decommissioning process for each plant for the $0 \%$ recycling scenario.

Table 6.

Facility Decommissioning Emissions.

KGR SNUPPS AP1000 W-SMR (Million $\mathrm{kg} \mathrm{CO}$-eq)

Facility and Building

Deconstruction 728

Radioactivity Measurements

44

Cutting and Decontamination

111
589

113 34 Interim storage 979 Total 1,861 36 7 17 2 90

3
140 718 1

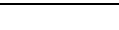

SMRs are designed with simplicity in mind therefore, the equipment used in the decommissioning phase will use less energy compared to a 1,000 MWe NPP. The GHG emissions generated from equipment use of a W-SMR scaled by the electrical output from a 1,000 MWe NPP. A uniform distribution representing the reduction in $\mathrm{GHG}$ emissions due to a reduction in equipment use with a lower bound of $0 \%$ and a higher bound of $20 \%$ is utilized. The lower bound parameter assumes there are no additional GHG emissions reductions from the modularity of SMRs, while the higher bound assumes a $20 \%$ reduction based on modularity (see Appendix A.7.1). This is applied by

\footnotetext{
${ }^{10}$ SAFSTOR (Safe Storage) is a strategy for decommissioning nuclear power plants where the dismantling and deconstruction is deferred to allow the radioactivity to decay to acceptable levels and the facility to be decontaminated. After this process the nuclear power plant is then dismantled.
} 
multiplying the W-SMR total facility decommissioning emissions with the difference between 100\% and the Construction Equipment Use Reduction distribution.

Chapman et al. (2012) estimate emissions from employees traveling to work during decommissioning at 1,000 $\mathrm{MW}_{\mathrm{e}} \mathrm{NPP}$. Table A-12 outlines the carbon emissions generated from transportation for these employees. Commuting trips for the W-SMR were scaled down based on the plants' electrical outputs. The decommissioning duration for the W-SMR is a uniform distribution where the minimum is scaled down based on the construction time of the AP1000 and the maximum is 10 years based on decommissioning workforce duration in (see Appendix A.9).

\section{Results}

A Monte Carlo simulation of 100,000 samples using the risk analysis software package@Risk was used with a chi-square binning arrangement of equal intervals to estimate the stochastic mean GHG emissions per kwh for each NPP. Figure 2 outlines the mean and $90 \%$ confidence interval emissions for the nuclear fuel cycle, construction, O\&M, decommissioning, and non-fuel related (construction, O\&M, and decommissioning) stages for each type of plant. The error bars in Figure 2 represent the $90 \%$ confidence interval. Figure A-3 identifies the distributions that have the most influence on the life cycle GHG emissions for the W-SMR.

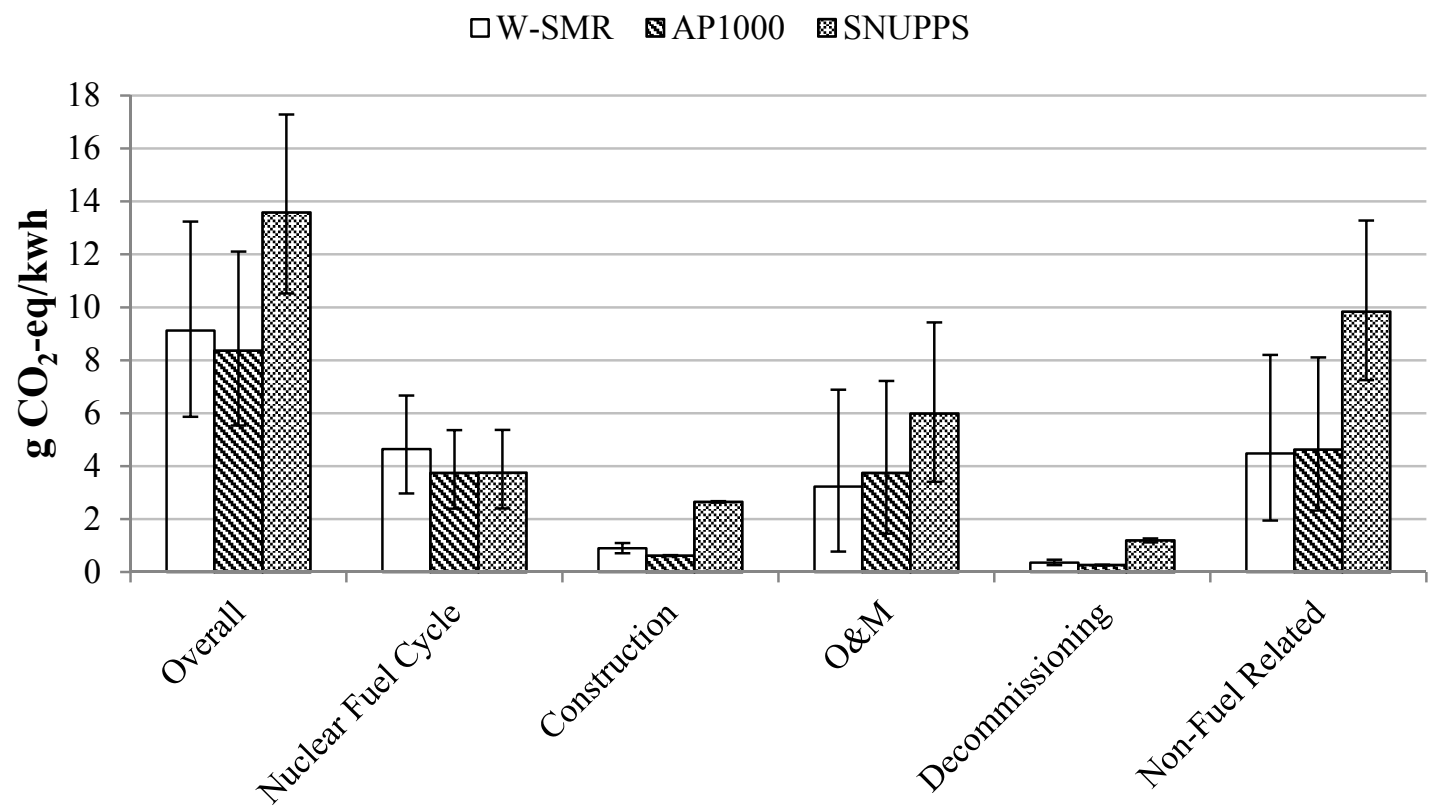

Life Cycle Stages 
Figure 2. Mean and 90\% confidence interval $\mathrm{CO}_{2}$-eq emissions for W-SMR, AP1000, and SNUPPS from Monte Carlo sampling.

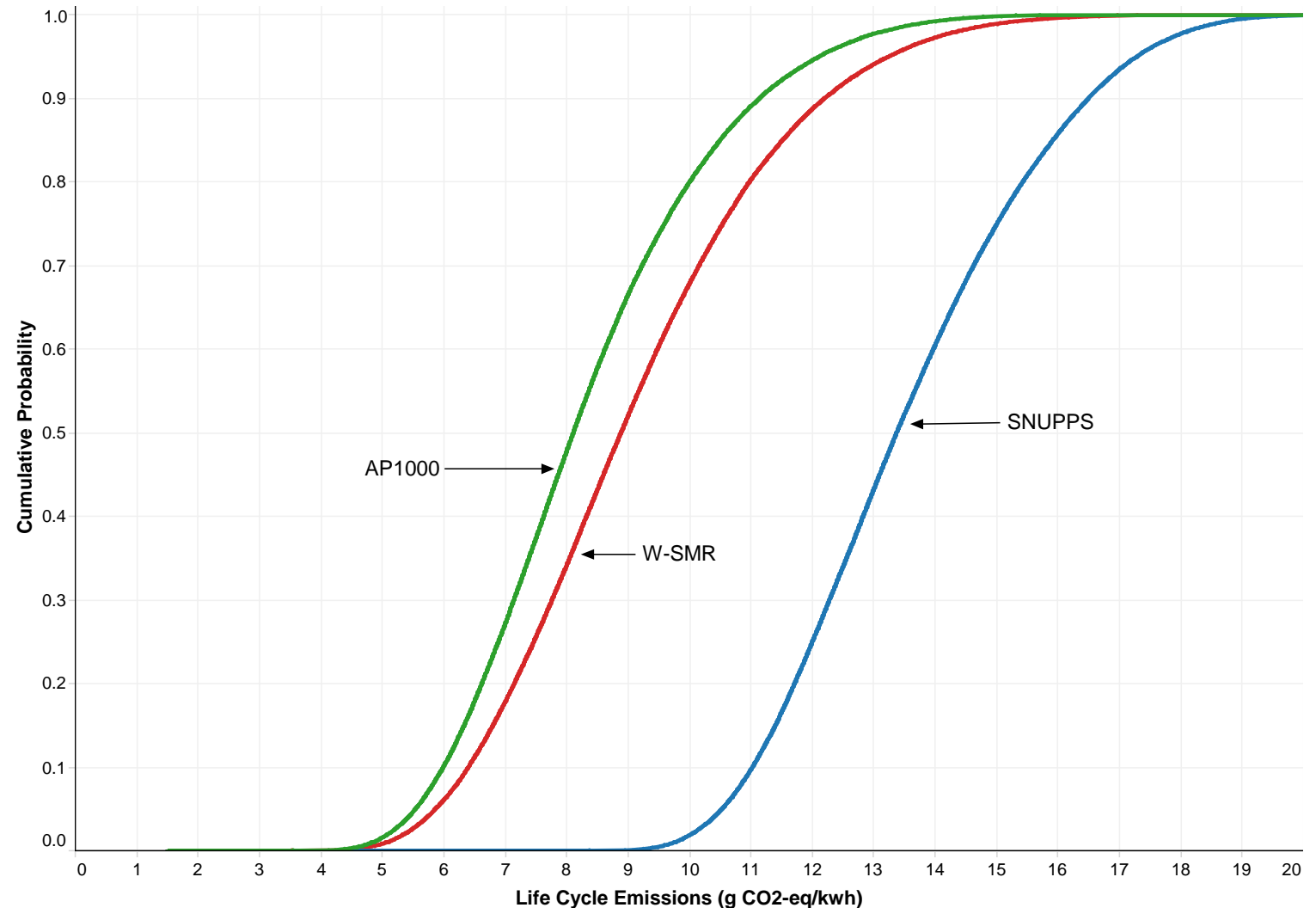

Figure 3 shows the cumulative distribution function produced by @Risk. 


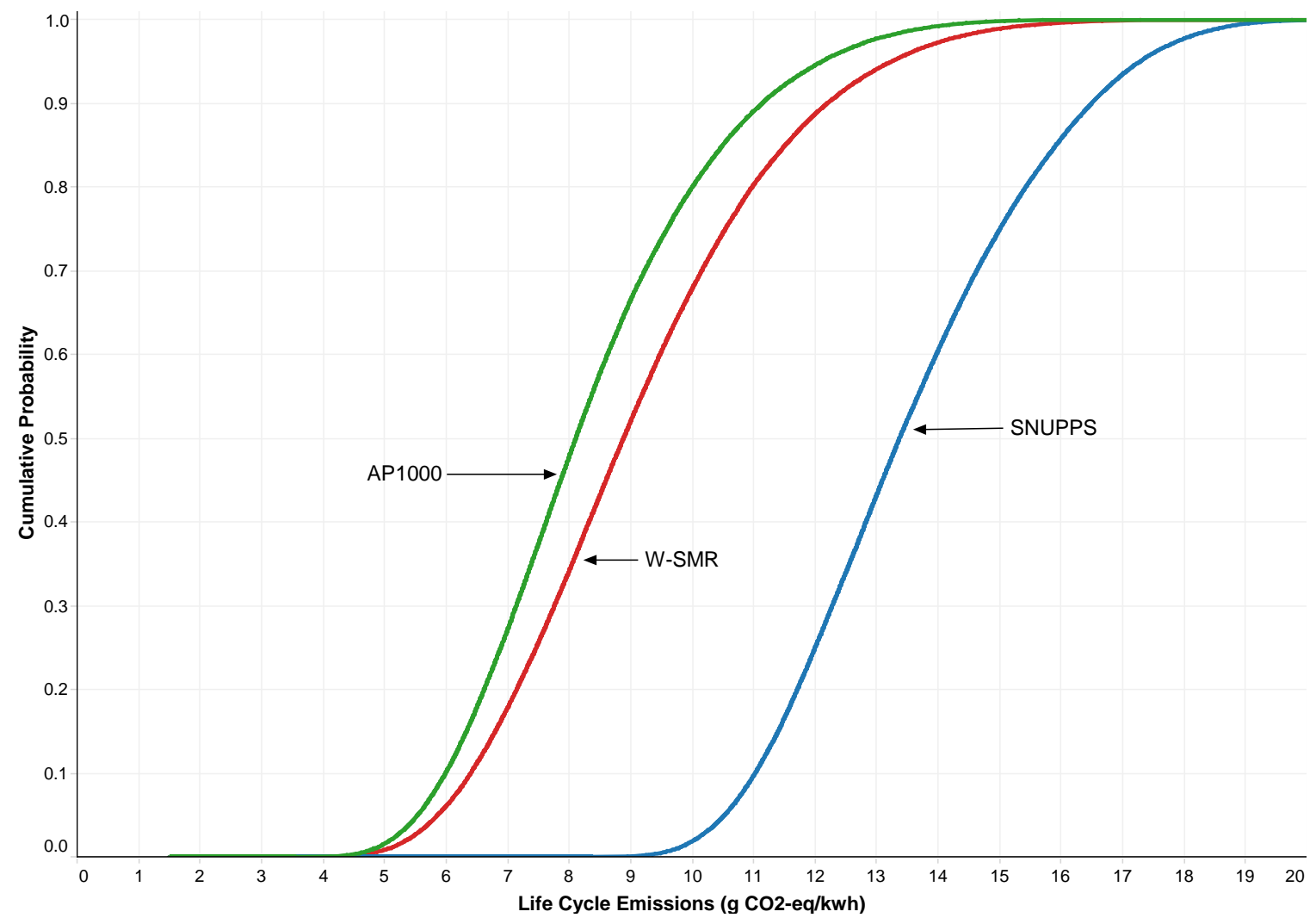

Figure 3. W-SMR, AP1000, and SNUPPS Cumulative Distribution Function Life Cycle Emissions.

The stochastic means, standard deviations, $90 \%$ confidence intervals of the distributions, and coefficient of variations (COVs) are shown for each power plant in Table 7. COVs are used as an important metric in this analysis because it illustrates the extent of variability in relation to the sample mean.

The W-SMR produces 9\% more life cycle GHG emissions than the AP1000. Because there is less than a $20 \%$ difference between the means and $90 \%$ confidence intervals, the difference is not significant in the real world [36]. As a result, their estimated life cycle GHG essentially the same. The differences between the Generation II and Generation III+ power plants are due to the construction, operation and maintenance, and decommissioning stages. The AP1000 and W-SMR, the SNUPPS and W-SMR, and the SNUPPS and AP1000 have a mean difference of $-0.8,4.5$, and $5.2 \mathrm{~g}$ of $\mathrm{CO}_{2}$-eq/kwh, respectively. Given the added estimated modularity, the W-SMR produces less GHG emissions than the AP1000 (AP1000 emissions - W-SMR emissions) 34\% of the time. 
On average the AP1000 and W-SMR produces $61 \%$ and $67 \%$ of the lifetime GHG emissions, respectively, compared to the SNUPPS. Appendix A.10 outlines the contribution each stage makes toward the total emissions. The SNUPPS generates the most GHG emissions per kwh of all the power plants within the construction, O\&M, and decommissioning stages. On average, the W-SMR produces less GHG emissions per kwh than the AP1000 in the O\&M stage while the AP1000 produces less GHG emissions per kwh during the construction and decommissioning stages.

When examining the non-fuel related stages, on average the W-SMR produces about the same GHG emissions per kwh as the AP1000 and less than the SNUPPS. In the scenario where the nuclear fuel is not considered, the AP1000 and the W-SMR, have a mean difference of $0.2 \mathrm{~g}$ of $\mathrm{CO}_{2}$-eq/kwh while the SNUPPS and W-SMR have a mean difference of $5.4 \mathrm{~g}$ of $\mathrm{CO}_{2}$-eq/ $\mathrm{kwh}$. The W-SMR is estimated to produce less GHG emissions per kwh than the AP1000 50\% of the time. On average the AP1000 and WSMR is estimated to produce $47 \%$ and $45 \%$ of the non-fuel related GHG emissions, respectively, of the SNUPPS. The W-SMR can reduce its life cycle GHG emissions by improving its thermal efficiency. By increasing its installed capacity to $260 \mathrm{MW}_{\mathrm{e}}$, matching the thermal efficiency of the AP1000, the W-SMR improves its life cycle GHG emissions to a mean (and $90 \%$ confidence interval) of $8.3 \mathrm{~g}$ of $\mathrm{CO}_{2}$-eq $/ \mathrm{kwh}$ (5.2 to $12.3 \mathrm{~g}$ of $\mathrm{CO}_{2}$-eq $\left./ \mathrm{kwh}\right)$.

In a low-carbon scenario where the emission factor of the U.S. electrical grid is 10 $\mathrm{g}$ of $\mathrm{CO}_{2}$-eq/kwh, the life cycle GHG emissions of the W-SMR and AP1000 shifts to 7.6 and $7.2 \mathrm{~g}$ of $\mathrm{CO}_{2}-\mathrm{eq} / \mathrm{kwh}$, respectively. Using a high-carbon scenario of coal only at about $980 \mathrm{~g}$ of $\mathrm{CO}_{2}$-eq/kwh we see the life cycle GHG emissions of the W-SMR and AP1000 shifts to 10.3 and $9.3 \mathrm{~g}$ of $\mathrm{CO}_{2}$-eq/kwh, respectively. 


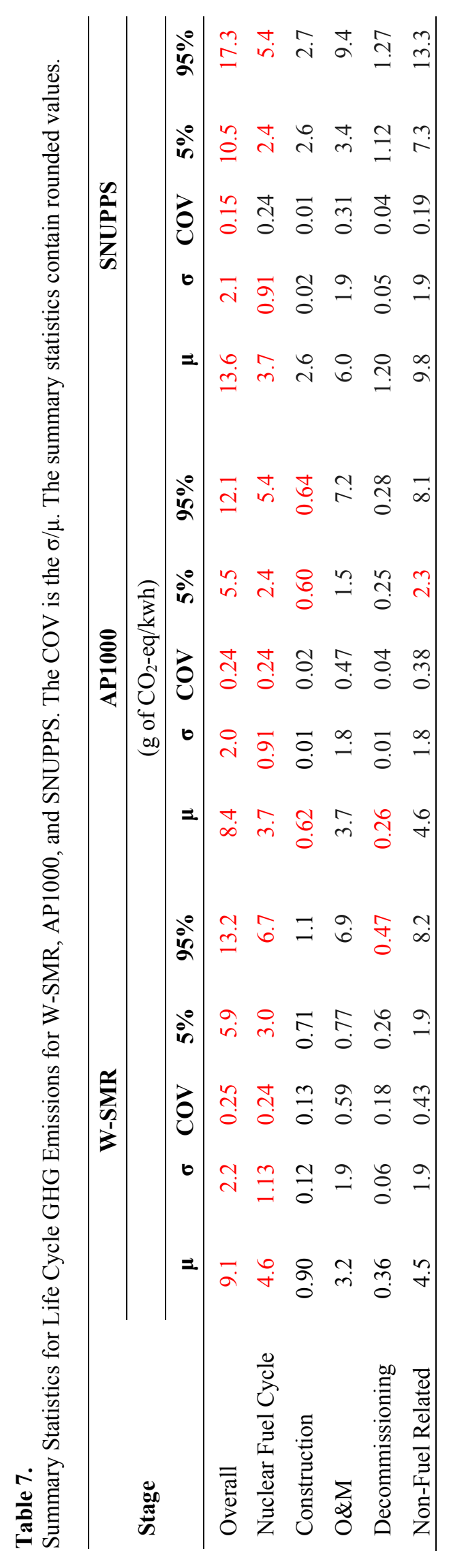




\subsection{Nuclear Fuel Cycle}

The nuclear fuel cycle calculations are common to all three designs. Table 7 shows a similar COV amongst all three NPPs because the distributions for the nuclear fuel cycle for all three plants are similar. Typically, the higher the enrichment percentage, the less enriched $\mathrm{UF}_{6}$ is produced during the nuclear fuel cycle (See Table 2 and Section 2.7). The AP1000 is estimated to have a burnup rate (fuel utilization) of around $50 \mathrm{GWd} /$ tonnes of U. It is assumed the W-SMR will have a similar burnup rate as the AP1000. This is possible due to the lower power density of the W-SMR. As a result, the W-SMR does not have as many safety related core design constraints as larger NPPs. Though the W-SMR and the AP1000 are estimated to have similar burnup rates, a lower thermal efficiency requires additional uranium to produce electricity. This results in the W-SMR producing more GHG emissions per kwh than the AP1000 and SNUPPS in the nuclear fuel cycle.

\subsection{Construction}

The amount of concrete and rebar in the SNUPPS and AP1000 is fairly certain based on the assumptions made in Table 1. The non-structural steel in an AP1000 was estimated from the distribution in Table 3. The non-structural steel of the SNUPPS was calculated by multiplying the non-structural steel in an AP1000 by 5. This is based on the ratio of about 5:1 when comparing the amount of rebar and concrete in a SNUPPS to AP1000 (See Table 1). As such the uncertainty represented by the COV shown in Table 7 for the AP1000 and SNUPPS is small compared to the W-SMR. The AP1000 and WSMR achieve first order stochastic dominance over the SNUPPS with lower construction emissions. Although the construction duration for AP1000 Unit 2 and 3 in South Carolina is expected to be, on average, about 6.5 years ${ }^{11}$, the overall results are relatively insensitive to this parameter (See Appendix A.10).

\subsection{Operation and Maintenance}

\footnotetext{
${ }^{11}$ VC Summer Unit 2: Construction Start date - 3/2013 [37], estimated completion date - 6/2019 [38]. VC Summer Unit 3: Construction Start date - 11/2013 [39], estimated completion date - 6/2020 [38].
} 
The estimates for operation and maintenance share the same initial uncertainty of the distributions found in White and Kulcinski (2000) and Fthenakis and Kim (2007). Though the reduction in non-structural steel reduces the mean emissions, the uncertainty around the amount of steel produces a larger COV for the W-SMR and AP1000 compared to the SNUPPS. Figure A-3 identifies the Standard Maintenance, Repair and Refurbishment and the ratio of W-SMR:SNUPPS steel distributions as the most influential for the W-SMR. The SMR / SNUPPS uniform distribution feeds directly into the Standard Maintenance, Repair and Refurbishment modularity factor.

\subsection{Decommissioning}

The energy needed to decommission each plant is scaled by total concrete of the KGR plant. Because the amount of concrete in W-SMR is uncertain, the emissions generated during decommissioning are also uncertain. The emission estimates for decommissioning are assumed to have minimal uncertainty for the AP1000 and SNUPPS based on the assumptions in Seier and Zimmerman (2014) and Chapman et al. (2012). Though the $100 \%$ recycling scenario distribution is the same for each plant, the uncertainty surrounding the amount of construction materials needed for the W-SMR contributes to the larger COV compared to the AP1000 and SNUPPS. The AP1000 outperforms the W-SMR in this stage because there is less uncertainty for the AP1000 than the W-SMR and the AP1000 generates more electricity over its lifetime than the WSMR.

\subsection{Non-Fuel Related (Construction, O\&M, and Decommissioning)}

The non-fuel related emissions are estimated by removing nuclear fuel cycle stages for the three types of NPPs. The COVs for the SNUPPS, AP1000, and W-SMR are $0.19,0.38$, and 0.43 . It is during the operation and maintenance stage where the W-SMR achieves its marginal superiority over the AP1000.

\subsection{Discussion}

To illustrate the overall competitiveness of the W-SMR, LCOE estimates from Abdulla and Azevedo (Revised and Resubmitted) [12] and the EIA [10] are combined with life cycle GHG emissions estimates presented here to determine if the W-SMR can be utilized as the best "middle option" for current PWR technologies. LCOE estimates for the $\mathrm{n}^{\text {th }}$ of a kind W-SMR and AP1000 sited in the southeastern US are from Abdulla 
and Azevedo (Revised and Resubmitted) using expert elicitation with a 3\% discount rate [12]. The LCOE estimates for the $\mathrm{n}^{\text {th }}$ of a kind W-SMR and AP1000 exclude owner's costs for site-work, transmission upgrades, etc. The EIA estimates transmission investment cost of \$1.1/MWh (2012\$) for advanced nuclear power plants [10]. GHG emission estimates for the SNUPPS falls within the estimated range of 9 to $110 \mathrm{~g} \mathrm{CO}_{2}$ eq/kwh for Generation II PWRs in the Warner and Heath (2012) harmonization study. Because of this, the SNUPPS is used to represent Generation II PWRs. Warner and Heath (2012) attributes the large variation in estimates to the primary source energy mix, the uranium enrichment method, the LCA method, and the future of uranium ore grade markets. LCOE estimates for the SNUPPS are based on the assumption that typically existing plants have paid off their initial capital cost [40]. Figure 4 shows that on average, the W-SMR and AP1000 outperform Generation II NPPs in life cycle emissions. All LCOE estimates are in 2012 dollars. 


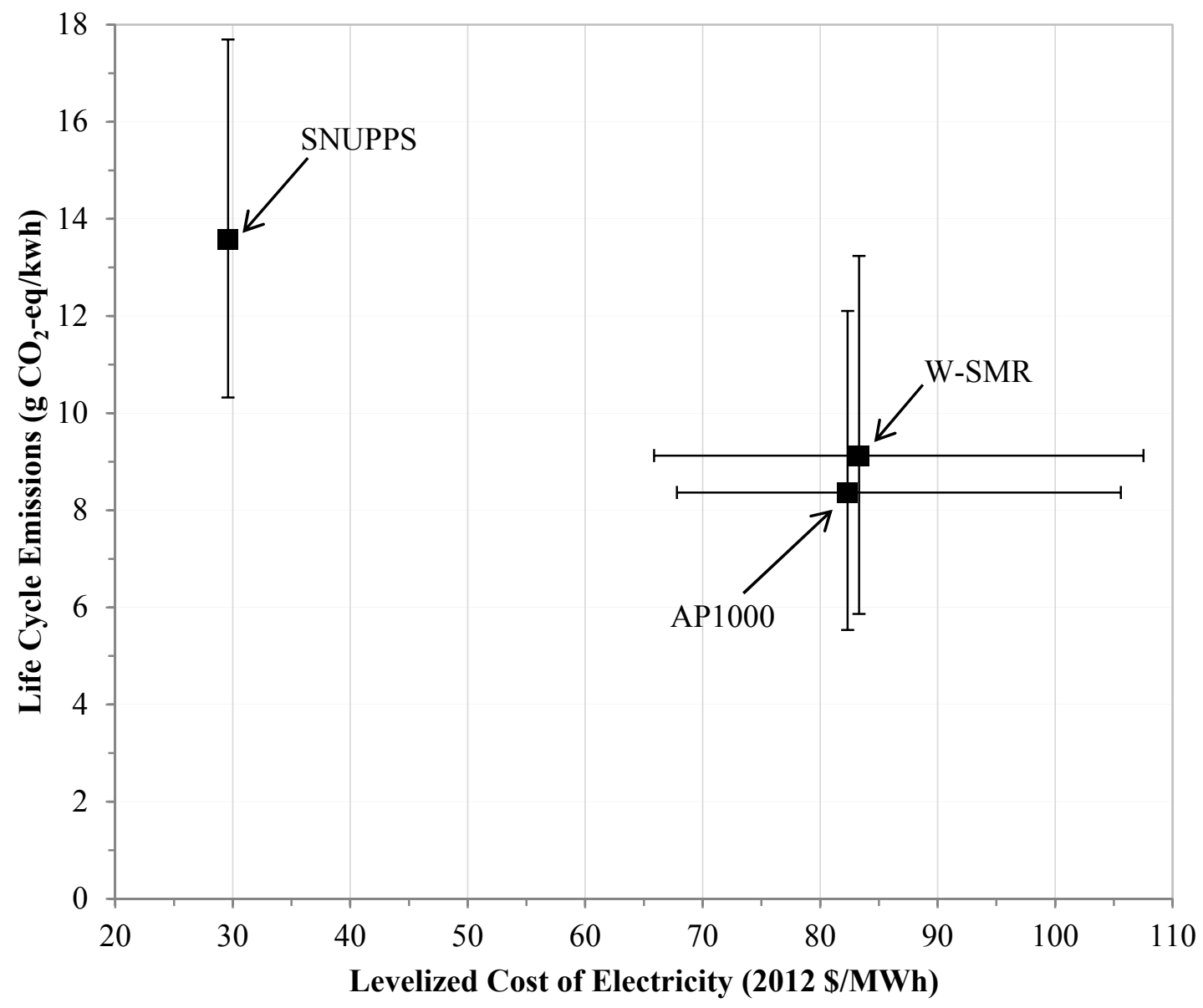

Figure 4. Nuclear Power Life Cycle GHG Emissions and LCOE Comparison. AP1000 and $\mathrm{n}^{\text {th }}$ of a kind W-SMR LCOE estimates (estimates are adjusted to 2012\$ using the US Bureau of Labor Statistics CPI Inflation calculator) exclude owner's costs for site-work, transmission upgrades, and etc. [12]. SNUPPS LCOE estimates cost [40].

Figure 5 compares the NPPs outlined in Figure 4 to other types of power plants. The life cycle GHG emission estimates are shown in log scale. Non-nuclear power plant GHG emission data points are sourced from the Intergovernmental Panel on Climate Change (IPCC) special report on renewable energy sources and climate change mitigation [41]. The LCOE estimates for the other non-nuclear energy sources entering service in 2019 are from the EIA's annual energy outlook [10]. 


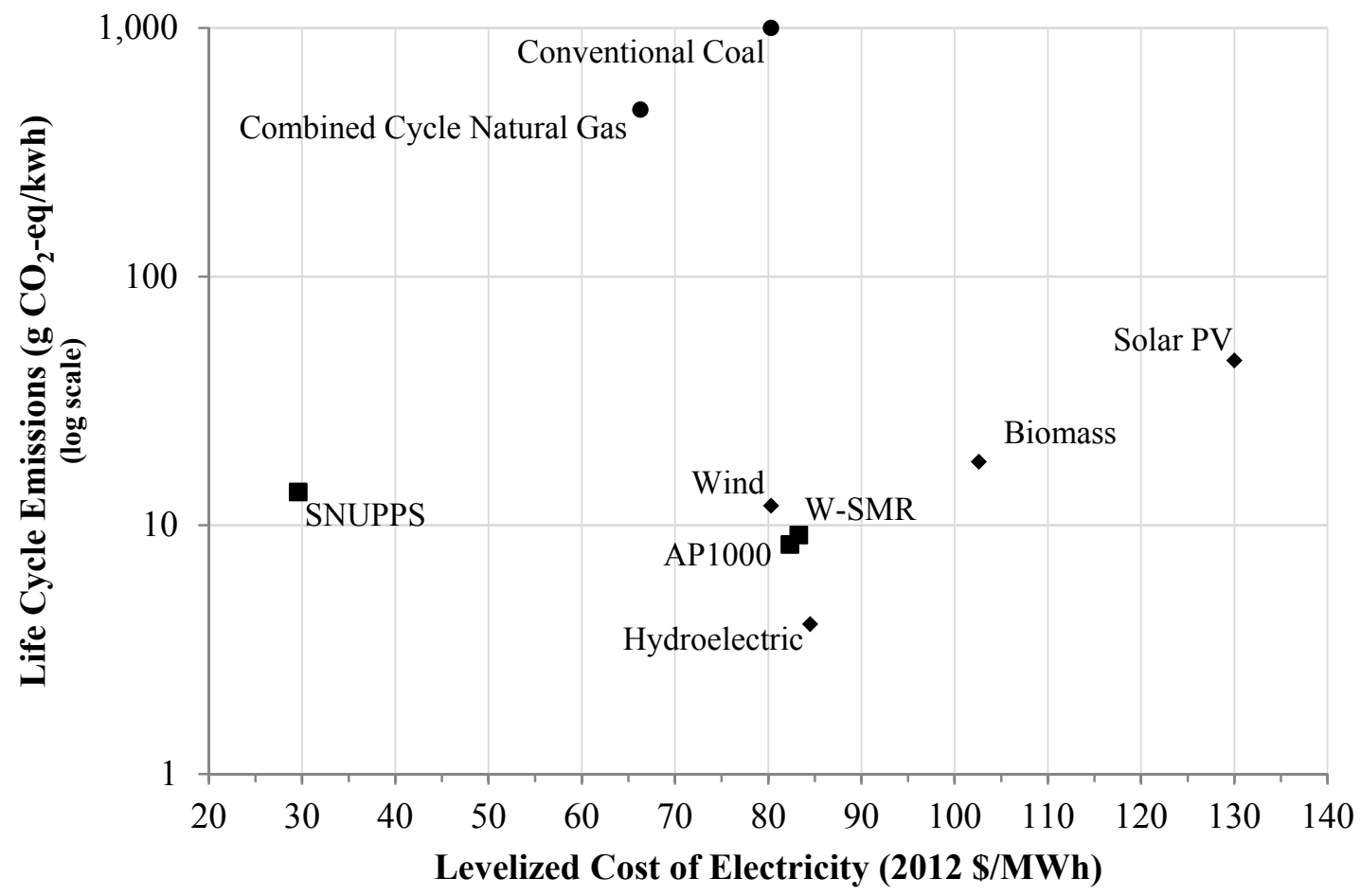

Figure 5. Electricity Generation Life Cycle GHG Emissions and LCOE Comparison. Nonnuclear LCOE data [10]. Non-Nuclear Emission data [41]. The LCOE for non-nuclear power sources represent plants entering service in 2019. The LCOE for conventional coal does not include a $\$ 15$ adder. This adder represents the cost of financing new coal plants without carbon capture technology to reflect the uncertainty of greenhouse gas legislation. A 3-percentage point adder is similar to a $\$ 15$ per metric ton emissions fee [42]. AP1000 and $n^{\text {th }}$ of a kind W-SMR LCOE estimates (estimates are adjusted to 2012\$ using the US Bureau of Labor Statistics CPI Inflation calculator) exclude owner's costs for site-work, transmission upgrades, and etc. [12]. SNUPPS LCOE estimates cost [40].

The W-SMR and the AP1000 on average perform the best for life cycle GHG emissions against all forms of energy generation except for hydropower plants. The AP1000 on average performs better than the W-SMR for LCOE and slightly for life cycle GHG emissions

Using the data presented in Figure 4 and Figure 5; it is possible to estimate the cost of carbon abatement by substituting coal and natural gas generation with nuclear generation. Assuming that coal and natural gas fired power plants produce lifetime GHG emissions of 1001 and $469 \mathrm{~g}$ of $\mathrm{CO}_{2}$-eq per kwh [41], the cost of carbon abatement with an AP1000 against coal and natural gas is $\$ 2 /$ tonne of $\mathrm{CO}_{2}$-eq (-\$13 to $\$ 26 /$ tonne of $\mathrm{CO}_{2}$ eq) and $\$ 35 /$ tonne of $\mathrm{CO}_{2}$-eq ( $\$ 3$ to $\$ 86 /$ tonne of $\mathrm{CO}_{2}$-eq), respectively. In comparison, a $\mathrm{W}-\mathrm{SMR}$ the cost of carbon abatement against coal and natural gas is $\$ 3 /$ tonne of $\mathrm{CO}_{2}$-eq 
(- $\$ 15$ to $\$ 28 /$ tonne of $\mathrm{CO}_{2}$-eq) and $\$ 37 /$ tonne of $\mathrm{CO}_{2}$-eq ( $\$ 1$ to $\$ 90 /$ tonne of $\mathrm{CO}_{2}$-eq), respectively. To put these into perspective, the EPA estimates the social cost of carbon to be between $\$ 16$ and $\$ 73 /$ tonne of $\mathrm{CO}_{2}$ by 2030 using a $\%$ and $2.5 \%$ discount rate in 2007 dollars, respectively [43].

\section{Conclusion and Policy Implications}

Nuclear power is a critical part of the US medium-term plan to reduce future carbon emission. To inform this discussion, this research is the first to complete LCAs for two designs of future nuclear power plants, the Generation III+ (AP1000) and the SMR (W-SMR). In terms of life cycle GHG emissions, both new designs have smaller footprints than existing SNUPPS. These benefits are achieved by the reduction in building materials and the extensive use of factory-fabricated components.

Differences between the two new designs result in similar footprints. While the AP1000 has the benefits of economies of scale, the W-SMR's modular ability enables it to make up some of the difference through efficiencies in construction, operation and maintenance, and decommissioning. Compared to the AP1000, the relatively low thermal efficiency of the W-SMR is a major contributor to its life cycle GHG emissions. The strength of the case for the W-SMR achieving similar life cycle GHG emissions as the AP1000 depends on the resolution of uncertainties in the construction, operation and maintenance, and decommissioning phases of the plants. With the exception of hydropower, the W-SMR and the AP1000 have a smaller footprint than all other generation technologies including renewables.

Estimates from the EIA [10] and expert elicitation show that the AP1000 and WSMR have a higher LCOE than natural gas and conventional coal. This trade-off between higher costs but lower GHG emissions demonstrates that depending on the value placed on carbon, SMR technology could be economically competitive with fossil fuel technologies (i.e., Generation III+ plants and SMRs can be viewed as a suitable middle option for climate-mitigation strategies).

Though this study does not include a long-term solution for final storage of spent nuclear fuel, nuclear power can be viewed as a reliable, low-carbon, base-load energy solution. With the early retirement of four nuclear power plants since 2012, the eventual retirement of older units in the nuclear fleet, and the United States pledging to reduce 
GHG emissions by $26 \%-28 \%$ over the next decade, installing new capacity using Generation III+ plants and SMRs creates an alternative for states and firms looking to comply with GHG emission regulation while providing base-load power to customers.

\section{Acknowledgements}

We would like to thank the National Science Foundation's Graduate Research Fellowship

Program under Grant No. 1252522 and the Center for Climate and Energy Decision Making (CEDM), through a cooperative agreement between the National Science Foundation and Carnegie Mellon University (SES-0949710) for providing support for this research project. We would like to thank Dr. Thomas V. Congedo and Jeffrey A. Brown his valuable feedback on the manuscript. 


\section{A. Appendix}

\section{A.1. SMR Key Features}

SMRs are designed with flexibility and reduced cost in mind. Below are some key features that may reduce the life-cycle GHG emissions:

- Longer refueling cycles. Generation II NPPs are typically refueled every 12-18 months, whereas it is expected that SMRs will need to be refueled at a minimum of every 24 months. There are some SMR designs that never have to be refueled during their lifetime. Within this design after the fuel is depleted, the core is removed for decommissioning.

- Increased thermal efficiency. Generation II and III+ NPPs typically have a thermal efficiency of $30 \%$ to $33 \%$. While this is also true for most SMR designs, the $\mathrm{EM}^{2} \mathrm{SMR}$ is claimed to achieve a thermal efficiency of around $48 \%$ [44]. This higher efficiency increases the amount of energy you receive per unit of fuel.

- Improved construction efficiency through modularity. Generation II NPPs are typically built on site. Generation III+ plants such as the Westinghouse AP1000 have introduced modularity into the design; as a result several structural and mechanical components are built in a factory and shipped to site where it is assembled. SMRs are designed to be totally modular in their design.

- Shorter, more efficient supply chain. SMRs are a fraction of the size of Generation II and III + plants. Typically Generation II and III + plant components are large leaving only a few vendors with the resources available to manufacture these components. SMRs will utilize smaller components meaning additional vendors can be included in the supply chain.

- Lower operation and maintenance cost. The simpler design of SMRs will employ fewer materials as well as have a majority if not all of their components fabricated in a factory. The benefits of having a simpler design will allow for fewer pumps, valves, and components. This will increase the quality and therefore reduce the amount of maintenance required during the lifetime of the plant.

- Reduction in construction time and mass production. Typically 7 years were needed to construct a Generation II NPPs. Generation III+ plants reduced this 
time to 5 years. SMRs have the ability to be mass produced reducing overall construction time. It is expected that some SMRs can be fully constructed in 18 months.

- Simpler decommissioning. Simpler methods of disassembly that will can involve disconnection of transportable modules that can be reused.

\section{A.2. Assumptions}

In 2012, 38\% of enriched uranium came from foreign suppliers [45]. Prior to May 2013, the U.S. was the only country that used gaseous diffusion to enrich uranium. After the United States Enrichment Corporation ceased operation of its Paducah, Kentucky gaseous diffusion plant, the U.S. has relied on gas centrifugation for uranium enrichment. Currently, Urenco's National Enrichment Facility in Eunice, New Mexico, provides domestic enrichment services.

\section{A.2.1. Historical and Scaled Estimates of Refueling Outage Duration}

Table A-1 outlines the historical average length of time each refueling period each year from 2000-2013. A scaled estimate for the refueling period was calculated for the W-SMR based on the electrical output.

Table A-1.

Historical and Scaled Estimates of Refueling Outage Duration.

\begin{tabular}{lrr}
\hline Year & $\mathbf{1 , 0 0 0}$ MW $_{\text {e }}$ (Days) & W-SMR (Days)* \\
\hline 2000 & 44 & 9.9 \\
2001 & 37 & 8.3 \\
2002 & 33 & 7.4 \\
2003 & 40 & 9.0 \\
2004 & 42 & 9.5 \\
2005 & 38 & 8.6 \\
2006 & 39 & 8.8 \\
2007 & 40 & 9.0 \\
2008 & 38 & 8.6 \\
2009 & 41 & 9.2 \\
2010 & 40 & 9.0 \\
2011 & 45 & 10.1 \\
2012 & 46 & 10.4 \\
2013 & 41 & 9.2 \\
Sample Mean & 40.29 & 9.06
\end{tabular}


Sample Standard Deviation

3.38

0.76

Note: The asterisk* indicates an extrapolated estimate based on the historical average of the $1,000 \mathrm{MW}_{\mathrm{e}}$ plant. 


\section{A.3. Mining \& Milling}

Uranium mining is the primary means for which NPPs are supplied with fuel. A majority of the world's known recoverable uranium is sourced from Australia, Kazakhstan, and Canada with $31 \%, 12 \%$, and $9 \%$ of the total fuel mined, respectively [27]. The process of open pit mining consists of drilling and using explosives in large open pits to remove rock covering the uranium ore. Underground shafts and excavation techniques are utilized when ore deposits are deeper. The in situ leaching process involves dissolving uranium ore in sulfuric acid.

The uranium milling operation typically takes place near the location of the mining operation. The mined uranium ore is crushed and leached in sulfuric acid to remove the impurities within the ore. The product of this process is a $70 \%$ to $90 \%$ uranium concentrate of $\mathrm{U}_{3} \mathrm{O}_{8}$ or "yellowcake."

Figure A-1 is a recreated plot from Norgate et al. (2014) that outlines the relationship between uranium ore grade and emissions for NPPs.

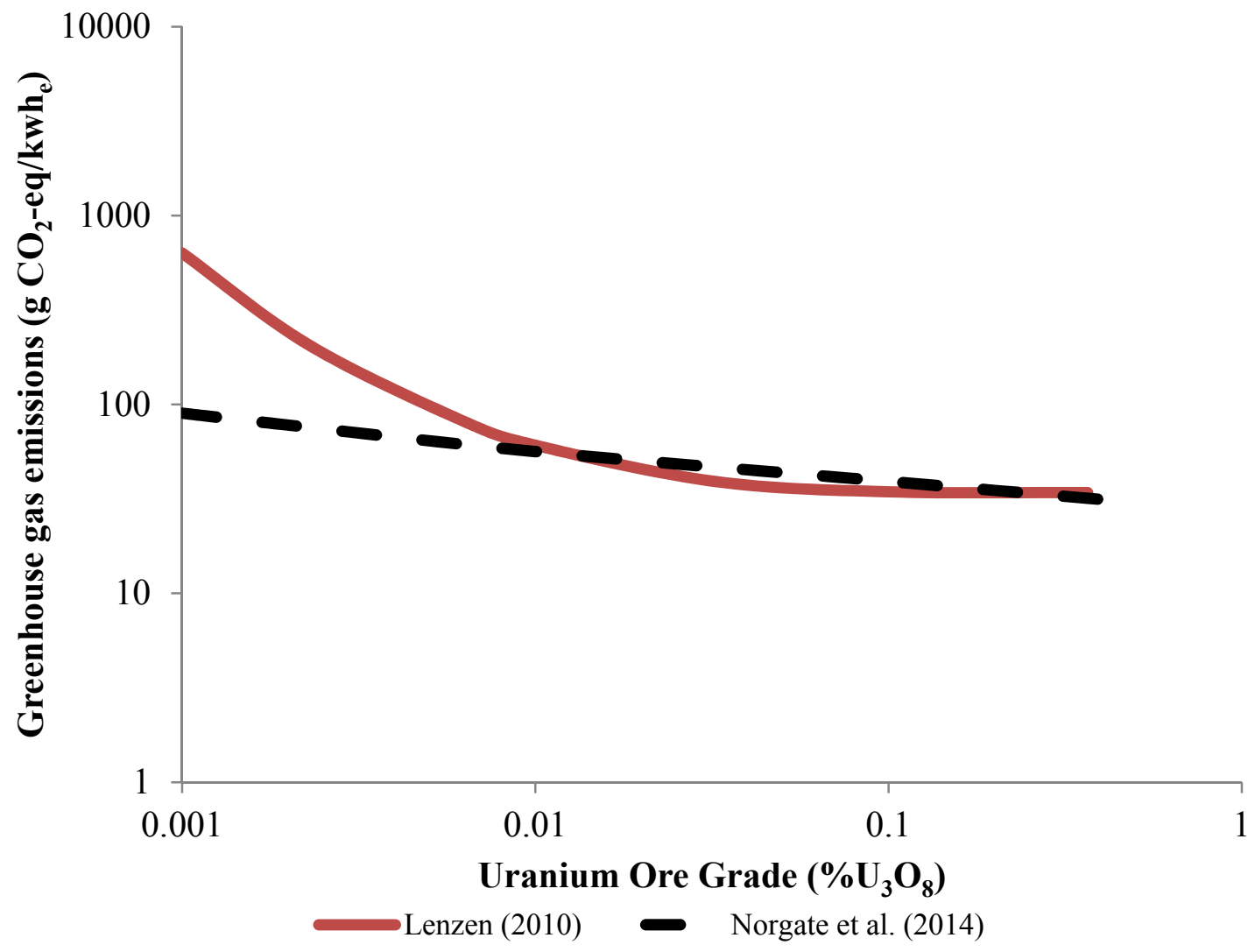

Figure A-1. Effect of Uranium Ore Grade on Emissions [18] 
The best estimate for the triangular distribution in table was calculated using the following equations:

$M M_{i}=$ Mining Method (as a percentage)

$i=(U G=$ Underground,$O P=$ Open pit, and $I S L=$ In situ leaching $)$

$W P U_{j}=$ World Production of Uranium from Mine (as a percentage)

$j=(R G M=$ Ranger Mine,$O D M=$ Olympic Dam Mine,$R S M$

$=$ Rossing Mine, $B V M=$ Beverly Mine, and $M R M=M c$ Arthur River Mine)

$M E_{j}=$ Median Mine Emissions $\left(t \mathrm{CO}_{2} / t \mathrm{U}_{3} \mathrm{O}_{8}\right)$

$R T=$ Representative total

$=W P U_{R G M}+W P U_{O D M}+W P U_{R S M}+W P U_{B V M}+W P U_{M R M}$

$B E=$ Best Estimate

$=M M_{U G}\left(M E_{O D M}\left(\frac{W P U_{O D M}}{R T}\right)+M E_{M R M}\left(\frac{W P U_{M R M}}{R T}\right)\right)$

$+M M_{O P}\left(M E_{R G M}\left(\frac{W P U_{R G M}}{R T}\right)+M E_{R S M}\left(\frac{W P U_{R S M}}{R T}\right)\right)+M M_{I S L}\left(M E_{B V M}\left(\frac{W P U_{B V M}}{R T}\right)\right)$

Equation A-1. Mining \& Milling Best Estimate Calculation

\section{A.4. Conversion}

The uranium conversion stage begins by feeding $\mathrm{U}_{3} \mathrm{O}_{8}$ into a $1,200^{\circ} \mathrm{F}$ fluidizedbed reactor where it reacts with hydrogen to form uranium dioxide $\left(\mathrm{UO}_{2}\right)$. The $\mathrm{UO}_{2}$ is fed into a fluidized-bed reactor at $1,000^{\circ} \mathrm{F}$ where it reacts with hydrogen fluoride (HF) to create uranium tetrafluoride $\left(\mathrm{UF}_{4}\right)$. The $\mathrm{UF}_{4}$ reacts with fluorine gas $\left(\mathrm{F}_{2}\right)$ to create $\mathrm{UF}_{6}$ [47]. The reaction is shown below:

$\mathrm{U}_{3} \mathrm{O}_{8}+2 \mathrm{H}_{2} \rightarrow 3 \mathrm{UO}_{2}+2 \mathrm{H}_{2} \mathrm{O}$

$\mathrm{UO}_{2}+4 \mathrm{HF} \rightarrow \mathrm{UF}_{4}+2 \mathrm{H}_{2} \mathrm{O}$

$U F_{4}+F_{2} \rightarrow U F_{6}$ 
Table A-2 [48] outlines the energy consumption estimates for uranium conversion from previous studies.

Table A-2.

Uranium Conversion Energy Consumption [48].

\begin{tabular}{lrrr}
\hline Reference Study & Year & $\begin{array}{r}\text { Electrical Energy } \\
\left(\mathrm{MWh}_{\mathrm{e}} / \mathrm{t} \mathrm{U}\right)\end{array}$ & $\begin{array}{r}\text { Thermal Energy } \\
\left(\mathrm{GJ}_{\mathrm{th}} / \mathrm{t} \mathrm{U}\right)\end{array}$ \\
\hline Areva & 2008 & 7.0 & 18.3 \\
Franklin et al & 1971 & 11.0 & 131 \\
Rombough \& Koen & 1974 & 15.1 & 234 \\
Rotty et al & 1975 & 14.6 & 1425 \\
SRI & 1975 & 10.3 & 1313 \\
Chapman & 1975 & 15.9 & 195 \\
Mortimer & 1977 & 12.1 & 235 \\
Torf et al. & 1998 & 10.3 & 700 \\
Mean & - & 12 & 531 \\
\hline
\end{tabular}

\section{A.5. Enrichment}

Typically, when uranium is mined the natural uranium is comprised of mainly 2 isotopes, $99.284 \% \mathrm{U}-238$ and $0.711 \% \mathrm{U}-235$. Within this enrichment process the amount of U-235 in UF 6 increases to $\leq 5 \%$. Typically diffusion requires between 2,400 and 3,000 $\mathrm{kwh} / \mathrm{SWUs}$ with a best estimate of 2,500 $\mathrm{kwh} / \mathrm{SWU}$ [49], whereas centrifuges require between 40 and $100 \mathrm{kwh} / \mathrm{SWUs}$ [33] with a best estimate of $50 \mathrm{kwh} / \mathrm{SWU}$ [49]. 


\section{A.6. Fuel Fabrication}

Table A-3 [48] outlines the energy consumption estimates for uranium fuel fabrication from previous studies.

Table A-3.

Fuel Fabrication Energy Consumption [48].

\begin{tabular}{lrrr}
\hline Reference Study & Year & $\begin{array}{r}\text { Electrical Energy } \\
\left(\mathrm{MWh}_{\mathrm{e} /} / \mathrm{t} \mathrm{U}\right)\end{array}$ & $\begin{array}{r}\text { Thermal Energy } \\
\left(\mathrm{GJ} \mathrm{J}_{\mathrm{th}} / \mathrm{t} \mathrm{U}\right)\end{array}$ \\
\hline Franklin et al & 1971 & 109.0 & 0 \\
USAEC & 1972 & 53.5 & 137 \\
Rombough \& Koen & 1974 & 168.8 & 6,169 \\
Rotty et al & 1975 & 303.0 & 2,720 \\
SRI & 1975 & 98.0 & 262 \\
Chapman & 1975 & 49.2 & 142 \\
Mortimer & 1977 & 65.0 & 341 \\
Orita & 1995 & 56.3 & 120 \\
Australian Coal Association & 2001 & 54.3 & 154 \\
Reported Mean & - & 105.3 & 1,101 \\
\hline
\end{tabular}

Note: This table contains reproduced from data from Norgate et al. (2010).

\section{A.7. Construction}

The dimensions of the AP1000, W-SMR, and GT-MHR containment building, reactor pressure vessel, and steel liner seen in Table A-4. The estimated mass of concrete and steel in each structure is detailed in Table A-4. A steel density of was assumed 7,850 $\mathrm{kg} / \mathrm{m}^{3}$. The total plant concrete of the W-SMR is scaled from the volume of concrete in an AP1000. The AP1000 and W-SMR steel liner volume were calculated assuming a cylindrical shape. The AP1000 and the GT-MHR shield building volume were calculated assuming a cylindrical shape, while the W-SMR was assumed to be cubic. The AP1000, W-SMR, and GT-MHR reactor vessel volume were calculated assuming a cylindrical shape.

Table A-4.

Concrete and Steel Mass Material Estimates [50-57].

\begin{tabular}{llrrr}
\hline Structure & Description & AP1000 & W-SMR & GT-MHR \\
\hline & Diameter $(\mathrm{m})$ & 39.62 & 9.75 & \\
& Height $(\mathrm{m})$ & 65.63 & 27.13 & \\
Steel Liner & Thickness (m) & 0.044 & 0.044 & N/A \\
(Nuclear Island) & Total Steel Volume* $\left(\mathrm{m}^{3}\right)$ & 471.9 & 43.3 & \\
& $\begin{array}{l}\text { Total Steel Liner* } \\
\text { (million kg) }\end{array}$ & 3.70 & 0.34 &
\end{tabular}




\begin{tabular}{|c|c|c|c|c|}
\hline \multirow{12}{*}{$\begin{array}{l}\text { Shield Building } \\
\text { (Nuclear Island) }\end{array}$} & Diameter (m) & 44.2 & N/A & 32.0 \\
\hline & Base (m) & N/A & 33.53 & $\mathrm{~N} / \mathrm{A}$ \\
\hline & Width (m) & N/A & 33.53 & N/A \\
\hline & Height (m) & 81.76 & 33.53 & 46 \\
\hline & Concrete (m) & 0.876 & 0.914 & 0.914 \\
\hline & Plate thickness $\times 2(\mathrm{~m})$ & 0.019 & 0 & 0 \\
\hline & Total Thickness (m) & 0.914 & 0.914 & 0.914 \\
\hline & $\begin{array}{l}\text { Volume* (thousand } \mathrm{m}^{3} \text { ) } \\
\text { Total Concrete Volume* }\end{array}$ & 12.7 & 5.8 & 5.4 \\
\hline & (thousand $\mathrm{m}^{3}$ ) & 12.2 & 5.8 & 5.4 \\
\hline & $\begin{array}{l}\text { Total Steel Volume* } \mathrm{m}^{3} \\
\text { Total plate Steel* }\end{array}$ & 514 & 0 & 0 \\
\hline & (million $\mathrm{kg}$ ) & 4 & 0 & 0 \\
\hline & $\begin{array}{l}\text { Total Plant Concrete } \\
\text { (Million kg) }\end{array}$ & 240 & $115^{*}$ & 52 \\
\hline \multirow{5}{*}{ Reactor Vessel } & Diameter (m) & 4.1 & 3.5 & 7.7 \\
\hline & Height (m) & 12.0 & 24.6 & 23.7 \\
\hline & Thickness (m) & 0.038 & 0.038 & 0.22 \\
\hline & Volume* $\left(\mathrm{m}^{3}\right)$ & 6.75 & 10.95 & 140 \\
\hline & $\begin{array}{l}\text { Total Steel Vessel* } \\
\text { (tonnes) }\end{array}$ & 53 & 85.9 & 1,098 \\
\hline Rebar & Weight (thousand tonnes) & 12 & 5.7 & $2.5^{*}$ \\
\hline
\end{tabular}

Note: The asterisk* indicates a calculated estimate

There are little data available on the total steel used in other areas of an AP1000.

Peterson et al. (2005) estimated the amount of metal in a 1,500 MW Economic Simplified Boiling Water Reactor (ESBWR). It is assumed that the unidentified metal has the same emissions factor as steel. The AP1000 has a total concrete volume of $100,000 \mathrm{~m}^{3}$, whereas the ESBWR has a total concrete volume of $104,000 \mathrm{~m}^{3}$ [58]. The similarity in concrete volume is used as justification for scaling the tonnage of metal used in the AP1000. The amount of metal for the W-SMR is scaled using the concrete volume of the AP1000. Table A-5 outlines the estimated tonnes of metal in the AP1000 and W-SMR.

\section{Table A-5.}

Additional Mass from Metal.

\begin{tabular}{lrrrr}
\hline & ESBWR & AP1000 & W-SMR & GT-MHR \\
\hline Concrete (thousand $\mathrm{m}^{3}$ ) & 104 & 100 & 48 & 21 \\
Turbine Building (tonnes) & 8,214 & 7,881 & 3,761 & N/A \\
Fuel Storage (tonnes) & 835 & 801 & 382 & 89 \\
Misc Buildings (tonnes) & 3,952 & 3,792 & 1,810 & N/A \\
Non-I\&C Reactor & & & & \\
Equipment (tonnes) & 6,526 & 6,261 & 2,988 & 4,050
\end{tabular}


Turbine Plant Equipment

(tonnes)

Miscellaneous Equipment

(tonnes)

Total Metal (tonnes)

$$
16,519
$$

1,176

1,128

37,222

35,711
7,564

538

17,404
N/A

617

4,756

Note: The total metal in the W-SMR is the reported mean from monte carlo simulation. This uncertain variable based on scaling the random draw from the AP1000 total metal uniform distribution by the volume of concrete. ESBWR and GT-MHR materials are sourced from Peterson et al. (2005).

The amount total metal outlined in the AP1000 is uncertain, to account for this a uniform distribution using a minimum of 35,711 tonnes and a maximum of 37,222 tonnes. Table 3 outlines parameters for the AP1000 total metal uniform distribution. The total metal for the W-SMR is scaled down based on the result from the uniform distribution of the AP1000.

\section{A.7.1. Modularity Reduction}

There is no data available on the benefits of modularity to a NPP. In addition to this, there is little data on the emission benefits of modular construction for any structure. Quale et al. (2012) performs a case study where the emissions from the construction of modular homes and traditional homes built on site. Based on the data provided in Quale et al. (2012). Table A-6 shows the reductions in GHG emissions from using modular construction methods.

Table A-6.

Modularity Reduction Factors Uniform Distribution ( $\mathrm{kg} \mathrm{CO}_{2}$-eq/2,000 $\mathrm{ft}^{2}$ home).

\begin{tabular}{lrrr}
\hline Description & $\begin{array}{r}\text { On-Site Average } \\
\left(\mathrm{kg} \mathrm{CO}_{2} \text {-eq) }\right.\end{array}$ & $\begin{array}{r}\text { Modular } \\
\text { Average } \\
\left(\mathrm{kg} \mathrm{CO}_{2} \text {-eq }\right)\end{array}$ & \% Reduction \\
\hline Materials Production & 780 & 613 & $21 \%$ \\
Construction Energy & & & \\
Use & 11,500 & 9,230 & $20 \%$ \\
Worker Transportation & 7,160 & 1,941 & $73 \%$ \\
\hline
\end{tabular}

The modularity reduction of a W-SMR is highly uncertain, to estimate this, the GHG reduction factor for materials was used as the minimum for concrete, rebar, and steel considering a modular home is far less complex than a NPP. Table A-7 outlines a modularity reduction maximum of a W-SMR for material use was estimated on the percent change from the scaled W-SMR estimate from the AP1000 to the scaled up estimate from the GT-MHR. 
Table A-7.

Modularity Reduction Factors Uniform Distribution Maximum.

\begin{tabular}{lrrr}
\hline Description & $\begin{array}{r}\text { Scaled From AP1000 } \\
\text { (Million kg) }\end{array}$ & $\begin{array}{r}\text { Scaled From GT-MHR } \\
\text { (Million kg) }\end{array}$ & \% Reduction \\
\hline W-SMR Concrete & 114.5 & 52.3 & $54 \%$ \\
W-SMR Rebar & 5.7 & 2.5 & $57 \%$ \\
W-SMR Steel & 17.8 & 5.1 & $71 \%$ \\
\hline
\end{tabular}

\section{A.7.2. Construction Workforce and Equipment Use}

Table A-8.

Construction Workforce $\mathrm{CO}_{2}$-eq Emissions.

\begin{tabular}{lrrr}
\hline & SNUPPS & AP1000 & W-SMR \\
\hline Electrical output (MWe) & 1,200 & 1,117 & 225 \\
Commuting Trips (round trips/day) & 1,000 & 1,000 & 1,000 \\
Commuting Distance (miles/round trip) & 40 & 40 & 40 \\
Commuting days (days/year) & 365 & 365 & 365 \\
Construction duration (years) & 8 & 5 & 2 \\
Total lifetime distance traveled (million miles) & 116.8 & 73 & 29 \\
Fuel Economy (miles/gallon) & 22 & 22 & 22 \\
Total fuel used (million gallons) & 5.4 & 3.4 & 1.4 \\
$\mathrm{CO}_{2}$ per gallon (tonnes) & 0.00892 & 0.00892 & 0.00892 \\
Total $\mathrm{CO}_{2}$ (thousand tonnes) & 48.2 & 30.1 & 12.4 \\
$\mathrm{CO}_{2}$ equivalent factor & 0.985 & 0.985 & 0.985 \\
Total (million kg of CO $\mathrm{CO}_{2}$-eq) & 49.0 & 30.6 & 12.6 \\
\hline Note: The construction duration, total lifetime distance traveled, total fuel used, total $\mathrm{CO}_{2}$ and $\mathrm{CO}_{2}$-eq \\
produced for the W-SMR are the reported means from Monte Carlo simulation. The parameters for the \\
distributions used are defined in Table 3.
\end{tabular}


Table A-9.

Annual Construction Equipment Use Emissions.

\begin{tabular}{lrr}
\hline Description & $\mathbf{1 , 0 0 0} \mathbf{M W}_{\mathbf{e}}$ & $\mathbf{W}-\mathbf{S M R}$ \\
\hline Earthwork and Dewatering (tonnes of $\mathrm{CO}_{2}$-eq) & 1,714 & 386 \\
Batch Plant Operations (tonnes of $\mathrm{CO}_{2}$-eq) & 486 & 0 \\
Lifting and Rigging (tonnes of $\mathrm{CO}_{2}$-eq) & 800 & 180 \\
Warehouse Operations (tonnes of $\mathrm{CO}_{2}$-eq) & 200 & 45 \\
Equipment Maintenance (tonnes of $\mathrm{CO}_{2}$-eq) & 143 & 32 \\
Total (tonnes of $\mathrm{CO}_{2}$-eq) & 3,343 & 643 \\
Total (million kg of $\mathrm{CO}_{2}$-eq) & 3.34 & 0.64 \\
\hline
\end{tabular}

\section{A.8. Operation, Maintenance, Repair, and Refurbishment}

It should be noted that fuel economy should improve over the next 60 years. An estimate of $22 \mathrm{mpg}$ is a conservative estimate.

Table A-10.

Operational Workforce $\mathrm{CO}_{2}$-eq emissions.

\begin{tabular}{lrr}
\hline & $\mathbf{1 , 0 0 0} \mathbf{~ M W}_{\mathbf{e}}$ & $\mathbf{W}-\mathbf{S M R}$ \\
\hline Commuting Trips (round trips/day) & 550 & 124 \\
Commuting Distance (miles/round trip) & 40 & 40 \\
Commuting days (days/year) & 365 & 365 \\
Lifetime (years) & 60 & 60 \\
Total lifetime distance traveled (million miles) & 482 & 108 \\
Fuel Economy (miles/gallon) & 22 & 22 \\
Total fuel used (million gallons) & 22.3 & 5.0 \\
$\mathrm{CO}_{2}$ per gallon (tonnes) & 0.00892 & 0.00892 \\
$\mathrm{CO}_{2}$ (thousand tonnes) & 199 & 45 \\
$\mathrm{CO}_{2}$ equivalent factor & 0.985 & 0.985 \\
Total (million kg of $\mathrm{CO}_{2}$-eq) & 202 & 45 \\
\hline
\end{tabular}

\section{A.9. Decommissioning}

NPPs are decommissioned when they reach their end of life, are too expensive to operate because of external economic factors, their licenses are terminated or are too expensive to repair. There are currently 11 NPPs in the U.S. that have been fully decommissioned [59]. The Nuclear Regulatory Commission (NRC) allows for three types of decommissioning, DECON or immediate dismantling, SAFSTOR or a deferred dismantling, and ENTOMB where the site is encased in concrete. This study will primarily focus on the SAFSTOR method. In the U.S., spent uranium fuel is contained 
inside concrete dry cask structures within range of the NPP. After the power plant is decommissioned the casks remain there until a permanent nuclear repository is developed. Table A-11 shows the GHG emissions generated from the construction of the concrete dry casks. These estimates assume the use of MAGNASTOR dry storage casks designed by NAC International [60]. The MAGNASTOR design was selected because it has the most recent certificate of compliance issue date [61].

Table A-11.

Interim Dry Cask Storage Emissions.

\begin{tabular}{lrrr}
\hline Description & SNUPPS & AP1000 & W-SMR \\
\hline Core Fuel Assemblies & 193 & 157 & 89 \\
Replaced Fuel Assemblies per Refueling Cycle & 64 & 52 & 30 \\
Lifetime Refueling Outages & 40 & 40 & 30 \\
Lifetime Total Fuel Assemblies & 2,573 & 2,093 & 890 \\
MAGNASTOR Assembly Capacity & 37 & 37 & 37 \\
Max Dry Cask Weight (tonnes) & 145 & 145 & 145 \\
Lifetime Casks & 70 & 57 & 24 \\
Fuel Assembly Weight (tonnes) & 0.66 & 0.66 & 0.66 \\
Total Fuel Assembly Weight (tonnes) & 1,693 & 1,377 & 585 \\
Total Max Dry Cask Weight (tonnes) & 10,095 & 8,212 & 3,491 \\
Empty Dry Cask Weight (tonnes) & 8,403 & 6,835 & 2,906 \\
Total (tonnes) & 3,361 & 2,734 & 1,162 \\
Total (million kg CO2-eq) & 3.4 & 2.7 & 1.2 \\
\hline
\end{tabular}

Table A-12 shows the GHG emissions generated from the decommissioning workforce.

Table A-12.

Decommissioning Workforce.

\begin{tabular}{lrr}
\hline & $\mathbf{1 , 0 0 0} \mathbf{~ M W}_{\mathbf{e}}$ & W-SMR \\
\hline Commuting Trips (round trips/day) & 200 & 45 \\
Commuting Distance (miles/round trip) & 40 & 40 \\
Commuting days (days/year) & 250 & 250 \\
Decommissioning duration (years) & 10 & 7 \\
Total lifetime distance traveled (million miles) & 20 & 3 \\
Fuel Economy (miles/gallon) & 22 & 22 \\
Total fuel used (thousand gallons) & 926 & 146 \\
$\mathrm{CO}_{2}$ per gallon (tonnes) & 0.00892 & 0.00892 \\
$\mathrm{Total}_{\mathrm{CO}}$ (tonnes) & 8,259 & 1,300 \\
$\mathrm{CO}_{2}$ equivalent factor & 0.985 & 0.985 \\
Total million $\mathrm{kg} \mathrm{CO}_{2}$-eq & 8.4 & 1.3 \\
\hline
\end{tabular}


Note: The decommissioning duration of the W-SMR is the reported mean from Monte Carlo simulation. The W-SMR decommissioning duration is an uncertain variable based on random draws from the uniform distribution from Table 3.

\section{A.10. Results}

Figure A-2 outlines the allocation each stage contributes to total emissions. There is a percentage reduction in the construction and decommissioning in the W-SMR and AP1000 when compared to the SNUPPS. This reduction is shifted over to the nuclear fuel cycle. This indicates that there is a GHG emission reduction from W-SMRs and AP1000s. If it is assumed the refueling outage duration for the W-SMR is the same as a large scale LWR (40 days) the life cycle GHG emissions would increase by $0.7 \%$ to 9.17 $\mathrm{g}$ of $\mathrm{CO}_{2}$-eq $/ \mathrm{kwh}$. In the extreme case where the refueling outage takes 500 days resulting in a capacity factor of $32 \%$, the life cycle GHG emissions would increase to the estimate of wind at about $12 \mathrm{~g}$ of $\mathrm{CO}_{2}$-eq $/ \mathrm{kwh}$. At 700 days with a capacity factor of $4 \%$, the life cycle GHG emissions would increase to the estimate of solar PV at about $45 \mathrm{~g}$ of $\mathrm{CO}_{2}-$ eq/kwh.

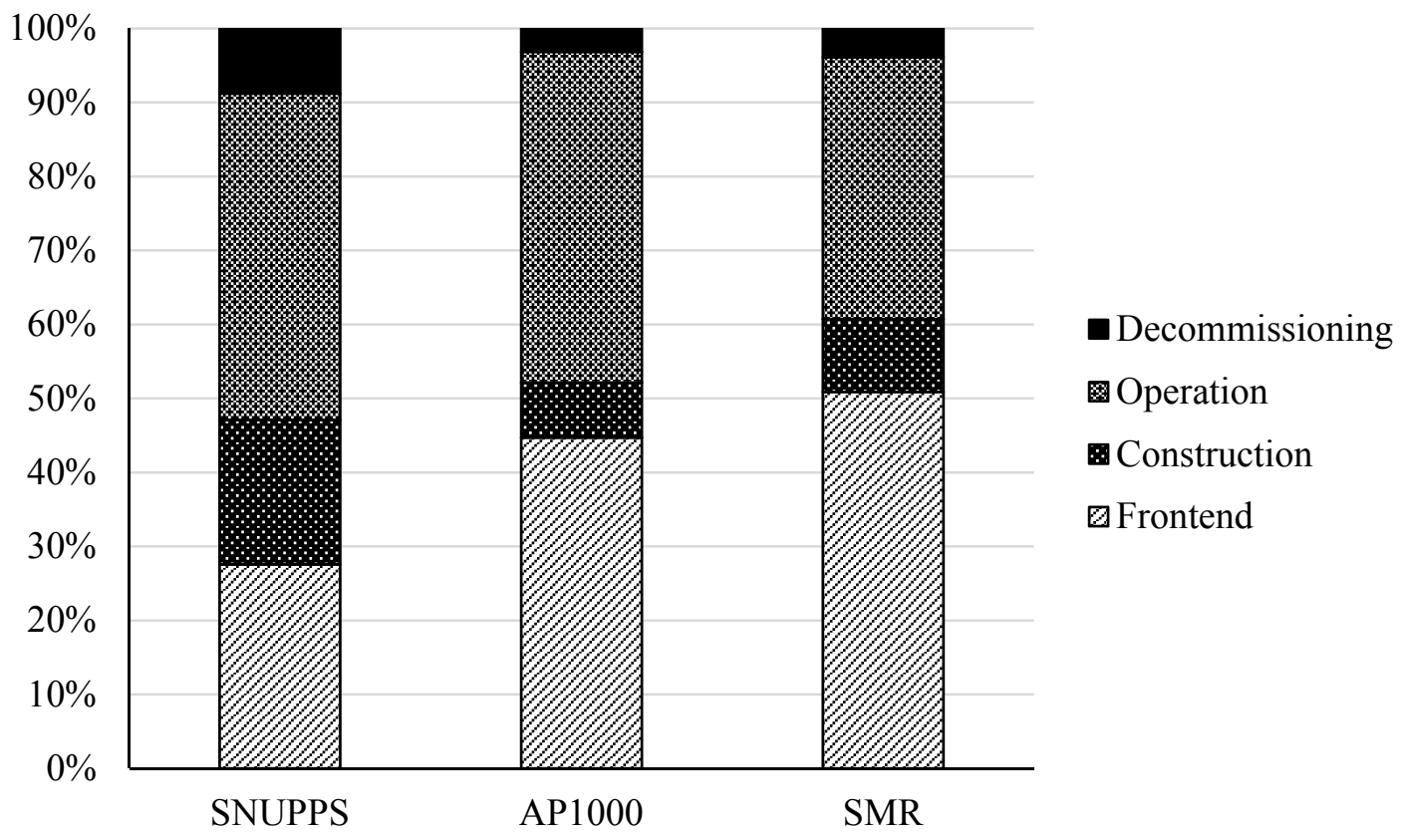

Figure A-2. Mean Share of Emissions. 
Assuming a worst-case scenario where the construction duration of a W-SMR is 6.5 years, the mean (and the $90 \%$ confidence interval) is shifted to $9.3 \mathrm{~g}$ of $\mathrm{CO}_{2}-\mathrm{eq} / \mathrm{kwh}$ ( 6.0 and 13.1 of $\mathrm{g} \mathrm{CO}_{2}$-eq/kwh). This represents a $2 \%$ increase from the original estimate of $9.1 \mathrm{~g}$ of $\mathrm{CO}_{2}$-eq/kwh. Based on this analysis, construction would have to take 75 years to produce the same life cycle GHG emissions as wind at about $12 \mathrm{~g}$ of CO2-eq $/ \mathrm{kwh}$. To produce the same life cycle GHG emissions as solar PV at about $46 \mathrm{~g}$ of CO2-eq/kwh the construction duration would be about 950 years. Figure A-3 shows the ten most influential distributions on the emissions from the W-SMR life cycle. Three variables are sourced from the nuclear fuel cycle while the others are from uncertainties in the construction and decommissioning duration, maintenance and operations, and modularity reduction rates from steel.

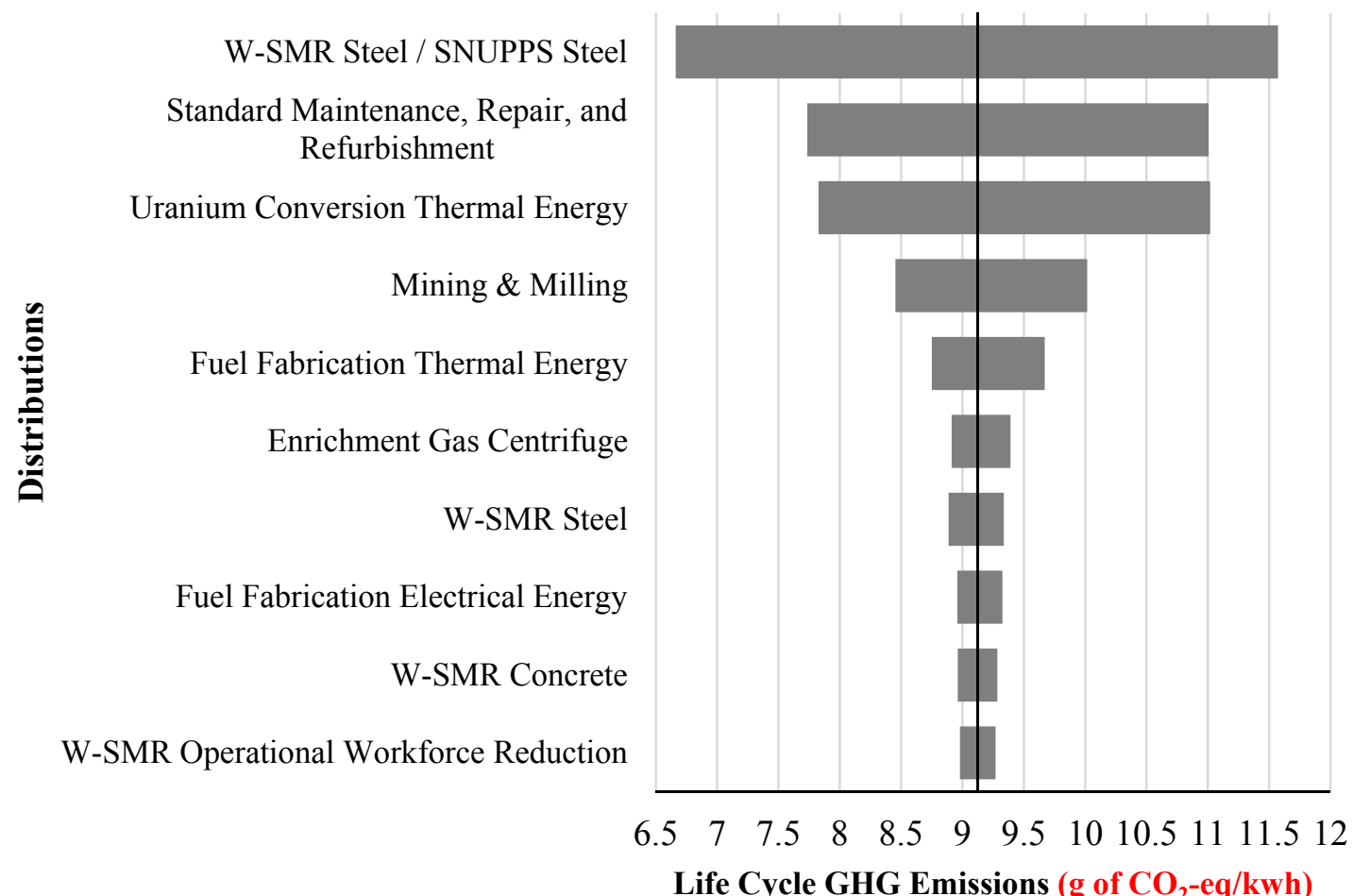

Figure A-3. Influential Distributions on W-SMR Emissions. Inputs ranked by effect on output mean. The baseline is $9.12 \mathrm{~g}$ of $\mathrm{CO}_{2}-\mathrm{eq} / \mathrm{kwh}$.

Figure A-4 outlines the correlation coefficients on influential distributions to the mean output emissions for the W-SMR. 


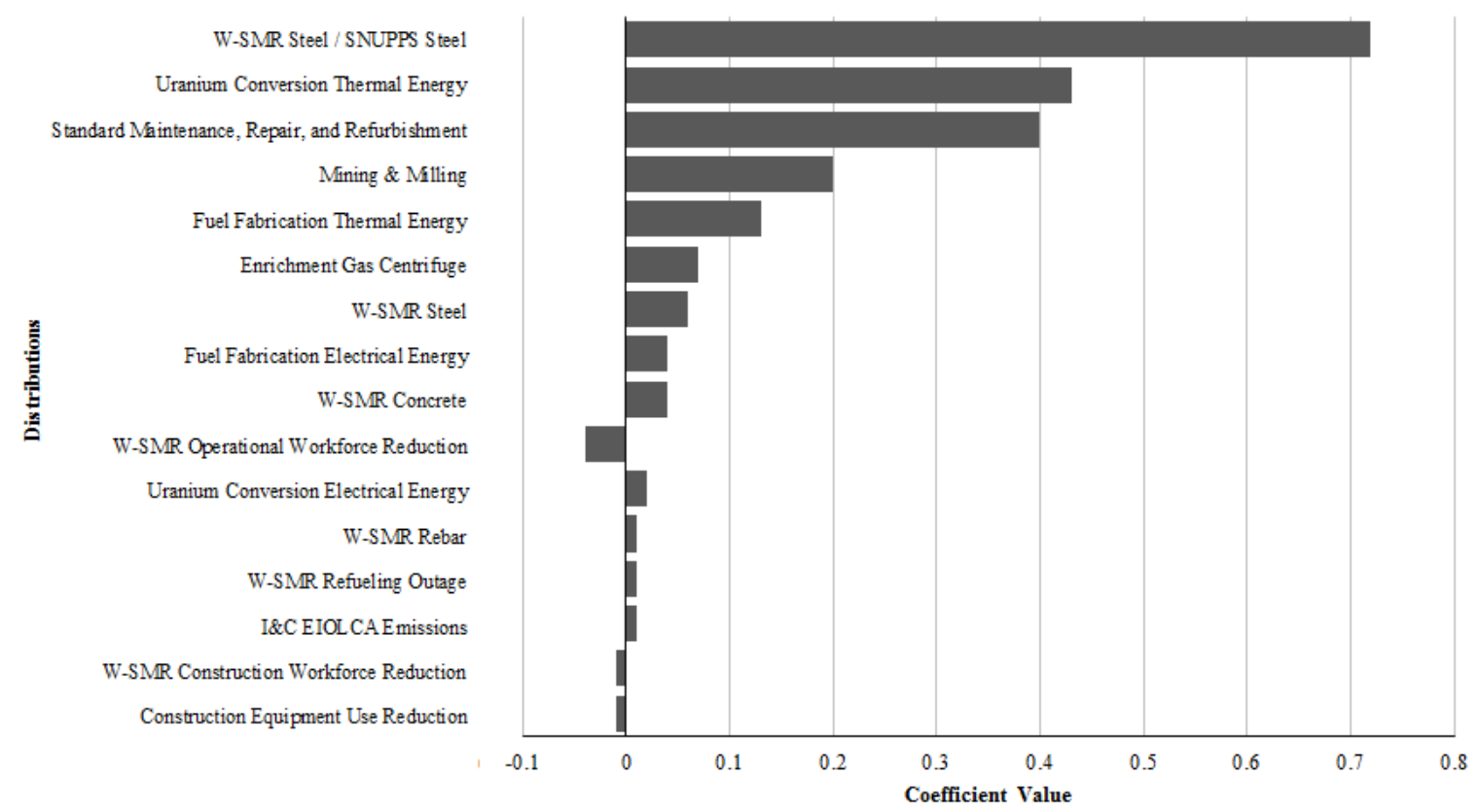

Figure A-4. Correlation Coefficients (Spearman Rank) on Influential Distributions on W-SMR Emissions 


\section{References}

[1] The White House, Office of the Press Secretary, 2015. FACT SHEET: U.S. Reports its 2025 Emissions Target to the UNFCCC. $<$ https://www.whitehouse.gov/the-pressoffice/2015/03/31/fact-sheet-us-reports-its-2025-emissions-target-unfccc $>$ (July 22, 2015)

[2] Enviornmental Protection Agency, 2015. Clean Power Plan for Existing Power Plants. $<$ http://www2.epa.gov/cleanpowerplan/clean-power-plan-existing-power-plants $>$ (December 4, 2015)

[3] EPA. Carbon Pollution Emission Guidelines for Existing Stationary Sources: Electric Utility Generating Units; Final Rule. In: Agency EP, editor. Federal Register: Federal Register; 2015. p. 64661-5120.

[4] Environmental Protection Agency, 2015. Overview of Greenhouse Gases Carbon Dioxide Emissions. $<$ http://www.epa.gov/climatechange/ghgemissions/gases/co2.html $>$ (June 17, 2015)

[5] EPA. Technical Support Document (TSD) for the CAA Section 111(d) Emission Guidelines for Existing Power Plants. In: Agency EP, editor.: Enviornmental Protection Agency; 2014.

[6] Mudd GM, Diesendorf M. Sustainability of Uranium Mining and Milling: Toward Quantifying Resources and Eco-Efficiency. Environmental Science \& Technology. 2008;42(7):2624-30.

[7] EIA. Annual Energy Outlook 2014 with projections to 2040. U.S. Energy Information Administration; 2014.

[8] Jiang M, Griffin WM, Hendrickson C, Jaramillo P, VanBriesen J, Venkatesh A. Life cycle greenhouse gas emissions of Marcellus shale gas. Environmental Research Letters. $2011 ; 6(3)$.

[9] Venkatesh A, Jaramillo P, Griffin WM, Matthews HS. Uncertainty in Life Cycle Greenhouse Gas Emissions from United States Natural Gas End-Uses and its Effects on Policy. Environmental Science \& Technology. 2011;45(19):8182-9.

[10] U.S. Energy Information Administration, 2014. Levelized Cost and Levelized Avoided Cost of New Generation Resources in the Annual Energy Outlook 2014.< http://www.eia.gov/forecasts/archive/aeo14/electricity_generation.cfm $>$ (December 30, 2014)

[11] U.S. Energy Information Administration, 2005. Energy Policy Act of 2005 Summary.< http://www.eia.gov/oiaf/aeo/otheranalysis/aeo_2006analysispapers/epa2005_summary.ht $\underline{\mathrm{ml}}>($ July 31,2015$)$ 
[12] Abdulla A, Azevedo IL. Developing a range of levelized cost estimates for integral light water small modular reactors. Energy Economics. Revised and Resubmitted.

[13] Sovacool BK. Valuing the greenhouse gas emissions from nuclear power: A critical survey. Energy Policy. 2008;36(8):2950-63.

[14] Warner ES, Heath GA. Life Cycle Greenhouse Gas Emissions of Nuclear Electricity Generation. Journal of Industrial Ecology. 2012;16:S73-S92.

[15] Beerten J, Laes E, Meskens G, D'haeseleer W. Greenhouse gas emissions in the nuclear life cycle: A balanced appraisal. Energy Policy. 2009;37(12):5056-68.

[16] Carnegie Mellon University Green Design Institute, 2008. Economic Input Output Life Cycle Assessment (EIO-LCA). $<$ http://www.eiolca.net $>$ (May 8, 2015)

[17] White SW, Kulcinski GL. Birth to death analysis of the energy payback ratio and $\mathrm{CO} 2$ gas emission rates from coal, fission, wind, and DT-fusion electrical power plants. Fusion Engineering and Design. 2000;48(3-4):473-81.

[18] Norgate T, Haque N, Koltun P. The impact of uranium ore grade on the greenhouse gas footprint of nuclear power. Journal of Cleaner Production. 2014;84:360-7.

[19] Makhijani A. Light Water Designs of Small Modular Reactors: Facts and Analysis. Institute for Energy and Environmental Research; 2013.

[20] Abdulla AY. Exploring the Deployment Potential of Small Modular Reactors: Carnegie Mellon University, 2014.

[21] Brown JA. Comparison of 4-Loop, AP100, SMR Equilibrium Cycle Fuel Requirements. In: Carless T, editor. The Environmental Competitiveness of Small Modular Reactors: A Life Cycle Study Comments ed2016. p. 1.

[22] Nuclear Engineering International, 2012. Digital switch.< http://www.neimagazine.com/features/featuredigital-switch// $>$ (May 7, 2015)

[23] Nuclear Energy Institute, 2014. US Nuclear Capacity Factors.< http://www.nei.org/Knowledge-Center/Nuclear-Statistics/US-Nuclear-Power-Plants/USNuclear-Capacity-Factors $>$ (December 25, 2014)

[24] Miller JS, Stakenborghs B, Tsai R. Improving Nuclear Power Plant's Operational Efficiences in the USA. 20th International Conference on Nuclear Engineering: ASME; 2012.

[25] World Nuclear Association, 2014. World Uranium Mining Production.< http://www.world-nuclear.org/info/Nuclear-Fuel-Cycle/Mining-of-Uranium/WorldUranium-Mining-Production/ > (December 25, 2014) 
[26] Nilsson J-A, Randhem J. Environmental Impacts and Health Aspects in the Mining Industry-A Comparative Study of the Mining and Extraction of Uranium, Copper and Gold: Chalmers University of Technology, 2008.

[27] World Nuclear Association, 2012. Uranium Mining Overview. $<$ http://www.worldnuclear.org/info/nuclear-fuel-cycle/mining-of-uranium/uranium-mining-overview/ > (November 20, 2014)

[28] EPA. eGRID 9th edition Version 1.0 Year 2010 Summary Tables. Enviornmental Protection Agency; 2014.

[29] Voorspools KR, Brouwers EA, D D'haeseleer W. Energy content and indirect greenhouse gas emissions embedded in 'emission-free'power plants: results for the low countries. Applied Energy. 2000;67(3):307-30.

[30] Schulz TL. Westinghouse AP1000 advanced passive plant. Nuclear Engineering and Design. 2006;236(14-6):1547-57.

[31] Quale J, Eckelman MJ, Williams KW, Sloditskie G, Zimmerman JB. Construction Matters: Comparing Environmental Impacts of Building Modular and Conventional Homes in the United States. Journal of Industrial Ecology. 2012;16(2):243-53.

[32] Chapman E, Rishel J, Niemeyer J, Cort K, Gulley S. Assumptions, Calculations, and Recommendations Related to a Proposed Guidance Update on Greenhouse Gases and Climate Change. Pacific Northwest National Laboratory; 2012.

[33] Fthenakis VM, Kim HC. Greenhouse-gas emissions from solar electric- and nuclear power: A life-cycle study. Energy Policy. 2007;35(4):2549-57.

[34] United States Nuclear Regulatory Commission, 2014. § 50.54 Conditions of licenses. $<$ http://www.nrc.gov/reading-rm/doc-collections/cfr/part050/part050-0054.html $>$ (December 20, 2014)

[35] World Nuclear Association, 2014. Nuclear Decommissioning: Decommission Nuclear Facilities. < http://www.world-nuclear.org/info/nuclear-fuel-cycle/nuclearwastes/decommissioning-nuclear-facilities/ > (December 26, 2014)

[36] Matthews HS, Hendrickson C, Matthews DH. Life Cycle Assessment: Quantitative Approaches for Decisions That Matter2015.

[37] International Atomic Energy Agency, 2016. Power Reactor Information System: SUMMER-2 (Virgil C. Summer 2). $<$ https://www.iaea.org/PRIS/CountryStatistics/ReactorDetails.aspx?current=1038 $>$ June 22, 2016)

[38] SCANA. The Public Service Commission of South Carolina Unanimously Approves South Carolina Electric \& Gas Company's Petition To Update Construction and Capital Cost Schedules For New Nuclear Units. South Carolina Electric \& Gas Company; 2015. 
[39] International Atomic Energy Agency, 2016. Power Reactor Information System: SUMMER-3 (Virgil C. Summer 3). $<$ https://www.iaea.org/PRIS/CountryStatistics/ReactorDetails.aspx?current=1039 $>$ June 22, 2016)

[40] Stacy TF, Taylor GS. The Levelized Cost of Electricity from Existing Generation Resources. Institute for Energy Research; 2015. p. 4.

[41] IPCC. Special Report on Renewable Energy Sources and Climate Change Mitigation. United Kingdom and New York, NY, USA: Cambridge University Press, 2011.

[42] U.S. Energy Information Administration, 2014. Market Trends: Emissions Concerns about future GHG policies affect builds of new coal-fired generating capacity. $<$ http://www.eia.gov/forecasts/archive/aeo14/MT emissions.cfm\#ghg_coalfired $>$ (June 6, 2015)

[43] U.S. Enviornmental Protection Agency, 2015. The Social Cost of Carbon.< http://www3.epa.gov/climatechange/EPAactivities/economics/scc.html $>$ (February 20, 2016)

[44] World Nuclear Association, 2014. Small Nuclear Power Reactors. $<$ http://www.world-nuclear.org/info/nuclear-fuel-cycle/power-reactors/small-nuclearpower-reactors $>$ (December 22, 2014)

[45] U.S. Energy Information Administration, 2013. The U.S. Relies on Foreign Uranium, Enrichment Services to Fuel Its Nuclear Power Plants.< http://www.eia.gov/todayinenergy/detail.cfm?id=12731 $>($ December 25, 2014)

[46] Nuclear Energy Institute, 2014. US Nuclear Refueling Outage Days. $<$ http://www.nei.org/Knowledge-Center/Nuclear-Statistics/US-Nuclear-Power-Plants/USNuclear-Refueling-Outage-Days $>$ (December 25, 2014)

[47] Tsoulfanidis N. The Nuclear Fuel Cycle: American Nuclear Society, 2013.

[48] Norgate T, Haque N, Koltun P, Tharumarajah A. Life Cycle Assessment of the Uranium Nuclear Power Cycle: Part 1 Once-through Cycle with Current Technologies. CSIRO National Research Flagships Minerals Down Under; 2010.

[49] World Nuclear Association, 2014. Uranium Enrichment.< http://www.worldnuclear.org/info/Nuclear-Fuel-Cycle/Conversion-Enrichment-and-Fabrication/UraniumEnrichment/ > (October, 2014)

[50] GA. Gas Turbine-Modular Helium Reactor Conceptual Design Description Report Rev. 1. General Atomics; 1996.

[51] Westinghouse Electric Company, LLC, 2003. The Westinghouse AP1000 Advanced Nuclear Plant.< 
http://www.apcnean.org.ar/arch/3e139fc91ebe2e675db2194460badc7c.pdf $>$ (December $29,2014)$

[52] WEC. AP1000 Design Control Document: Design of Structures, Components, Equipment and Systems Rev. 14. In: Commission USNR, editor.: Westinghouse Electric Company, LLC; 2008.

[53] Westinghouse Electric Company LLC, 2009. AP1000 Design Overview.< http://www.atomeromu.hu/download/1676/AP\%201000\%20reaktor.pdf $>$ (December 29, 2014)

[54] ONR. Generic Design Assessment - New Civil Reactor Build Step 4 Civil Engineering and External Hazards Assessment of the Westinghouse AP1000® Reactor. In: Regulation OfN, editor.: Office for Nuclear Regulation; 2011.

[55] WEC. AP1000 Design Control Document: Design of Structures, Components, Equipment and Systems Rev. 19. Westinghouse Electric Company, LLC; 2011.

[56] Vujić J, Bergmann RM, Škoda R, Miletić M. Small modular reactors: Simpler, safer, cheaper? Energy. 2012;45(1):288-95.

[57] Westinghouse Electric Company, LLC, 2013. Nuclear Power A Journey of Continuous Improvement. $<$ https://engineering.tamu.edu/media/948603/bowser_ppt.pdf $>$ (December 29, 2014)

[58] Peterson PF, Zhao H, Petroski R. Metal and concrete inputs for several nuclear power plants. University of California Berkeley; 2005.

[59] Nuclear Regulatory Commission, 2014. Backgrounder on Decommissioning Nuclear Power Plants. $<$ http://www.nrc.gov/reading-rm/doc-collections/factsheets/decommissioning.html $>$ (December 26, 2014)

[60] Subiry JC. The Evolution to Ultra-high Capacity Dry Storage Casks

An Update on MAGNASTOR ${ }^{\circledR}$ Technology. Conference The Evolution to Ultra-high Capacity Dry Storage Casks

An Update on MAGNASTOR ${ }^{\circledR}$ Technology, Vienna, Austria. NAC International.

[61] United States Nuclear Regulatory Commission, 2015. Dry Spent Fuel Storage Designs: NRC Approved for General Use. $<$ http://www.nrc.gov/waste/spent-fuelstorage/designs.html $>$ (February 22, 2016) 